\title{
Significance, detection and markers of disseminated breast cancer cells
}

\author{
Marc Lacroix ${ }^{1,2}$
}

\author{
${ }^{1}$ Laboratoire Jean-Claude Heuson de Cancérologie Mammaire, Institut Jules Bordet, Bruxelles, Belgium \\ ${ }^{2}$ InTextoResearch, 4, chemin de Hoevel, B-4837 Baelen, Wallonia, Belgium \\ (Requests for offprints should be addressed to M Lacroix who is now at InTextoResearch, 4, chemin de Hoevel, B-4837 Baelen, \\ Wallonia, Belgium; Email: itr@iname.com)
}

\begin{abstract}
The development of distant metastases is the major cause of death from breast cancer. In order to predict and prevent tumour spreading, many attempts are being made to detect small numbers of tumour cells that have shed from the primary lesions and have moved to lymph nodes, blood or bone marrow. This article presents the advantages and the limitations of techniques used for disseminated tumour cells (DTC) detection. DTC markers are listed and the most currently used of them (KRT19, CEACAM5, TACSTD1, MUC1, EGFR, ERBB2, SCGB2A2, SCGB2A1, SCGB1D2, PIP, SBEM, TFF1, TFF3, ANKRD30A, SPDEF, ESR1, SERPINB5 and GABRP) are discussed, notably on the basis of recent data on breast tumour portraits (luminal epithelial-like, basal/myoepithelial-like and ERBB2). The significance of DTC for the prognosis and prediction of response to therapy is examined. DTC viability, the notion of cell dormancy and the concept of breast cancer stem cells are also discussed.
\end{abstract}

Endocrine-Related Cancer (2006) 13 1033-1067

\section{Introduction}

Despite the improvements in detection and the treatment of breast cancer, about $40 \%$ of patients still succumb to the disease. The development of distant metastases is the major cause of these deaths. Breast cancer is generally no longer curable once metastases are detected by 'classical' means: clinical manifestations of the spread, imaging methods (such as tomography) and serum marker assays, such as those based on carcinoma antigen 15.3 (CA15.3) or carcinoembryonic antigen (CEA).

According to a longstanding hypothesis, breast cancer dissemination should involve a succession of clinical and pathological stages starting with carcinoma in situ, progressing into invasive lesion and culminating in metastatic disease. Moreover, it was thought for decades that metastasizing breast cancer cells (BCC) first disseminated to the lymph nodes (LN) before reaching peripheral blood (PB) and distant locations, including bone marrow (BM). Unfortunately, it has now became clear that metastatic spreading occurs in about $50 \%$ of cases with apparently localized breast cancer, and that up to $30 \%$ of patients with LN-negative disease will develop distant metastases within 5 years (Fisher et al. 2002, Gilbey et al. 2004, Pantel \& Brakenhoff 2004, Zieglschmid et al. 2005). Therefore, recurrence is probably due to the establishment of micro-metastases before primary loco-regional treatment. That BCC seem occasionally able to shed from the primary lesion very early in the natural history of tumours, and that a direct haematogenous dissemination route is likely to exist that bypasses the lymphogenous one, strongly supports the search for techniques and tumour markers able to unambiguously identify disseminated tumour cells (DTC). This should allow evaluating the potential of these DTC in predicting the development of metastases and monitoring the response of patients to various adjuvant or neoadjuvant therapies.

\section{Dissemination sites: lymph nodes, peripheral blood, bone marrow}

Historically, the detection of DTC is most important in pathological staging of LN specimens. In the last few years, the presence of DTC in BM has also been shown to provide prognostic information. Promising detection strategies for DTC in PB are also being evaluated. 


\section{Lymph nodes (LN)}

In breast cancer, the risk of metastatic disease is classically estimated by factors, such as tumour size, tumour grade, oestrogen (ESR1) and progesterone (PGR) receptor status, ploidy, ERBB2 (HER2/neu) overexpression and the number of positive axillary lymph nodes (ALN). Numerous studies have shown that the presence of DTC in ALN is the most powerful prognostic factor, being associated with significantly poor disease-free (DFS) and overall survival (OS; for instance, see Valgussa et al. 1978, International (Ludwig) Breast Cancer Study Group 1990, Cote et al. 1999, Braun et al. 2001a, Hawes et al. 2001, Pantel \& Brakenhoff 2004).

During the last years, the concept of sentinel lymph node (SLN) has emerged. SLN biopsy implements mapping of the one or two LN that primarily drain the tumour (the 'sentinel nodes') and therefore are most likely to harbour the metastatic disease. SLN analysis is now extensively performed in breast cancer, as it can provide prognostic value with minimal-associated morbidity in contrast to complete ALN dissection. The prescreening of SLN with highly sensitive detection methods for micro-metastases thus represents a promising approach.

Considering that significant numbers of LN-negative patients develop metastatic disease, the reliability of current staging procedures to detect DTC in LN has been questioned (see 'Techniques for DTC detection').

\section{Peripheral blood (PB)}

PB is historically one of the most important diagnostic specimens. For instance, circulating tumour markers have been monitored in serum for years to provide indicative values about metastatic or emerging primary breast cancer. Serum markers may be good indications for tumour load, yet in most cases they fail to provide information about minimal residual disease.

Technically speaking, PB appears as an ideal source for the monitoring of DTC. Indeed, PB sampling is relatively painless and can be done at frequent intervals (for instance, to allow an assessment of the patient's recovery or potential to develop metastases). Many groups have demonstrated the presence of DTC in PB of patients with early-stage cancer without overt metastases (for instance, see Gaforio et al. 2003, Pierga et al. 2004, Cristofanilli et al. 2005a, Müller et al. 2005, Benoy et al. 2006, Wülfing et al. 2006 and the reviews of Gilbey et al. 2004, Pantel \& Brakenhoff 2004, Ring et al. 2004, Zieglschmid et al. 2005).

\section{Bone marrow (BM)}

In contrast to $\mathrm{PB}$ sampling, $\mathrm{BM}$ aspiration during surgery (mostly from the medullary space of iliac crest, a site of intensive cellular exchange between blood and the mesenchymal interstitium) appears time consuming and uncomfortable for the patient. However, among the distant organs, BM is a common homing site for DTC derived from breast cancer and other primary carcinoma, even in the absence of $\mathrm{LN}$ metastases or clinical signs of overt distant metastases (see notably the review of Pantel \& Brakenhoff 2004). In fact, the detection rate of DTC in BM from nonmetastatic breast cancer patients has been reported to be in the range from 0\% (Fetsch et al. 2000) to $100 \%$ (Slade et al. 2005), and this illustrates the variability of results obtained by the use of different techniques or marker genes (see 'Techniques for DTC detection'). In a recent, large (more than 3500 cases) study of stages I-III breast cancer patients, the incidence of DTC in BM detected by immunocytochemistry (ICC) ranged from 13 to $43 \%$ (Braun \& Naume 2005).

The presence of DTC in BM may be useful not only in predicting the development of bone metastases, but also in predicting the development of metastases in other distant organs, such as lung and liver. To date, however, it remains unknown whether $\mathrm{BM}$ is a reservoir that allows for DTC to adapt and disseminate later into other organs, or whether the presence of DTC in BM might reflect the general propensity of these cells to disseminate and survive in organs, rather than just in the BM. Until methods are developed to detect the presence of DTC in organs, such as the lung or liver, it will not be possible to distinguish between these two possibilities. That BM could serve as a reservoir in breast cancer is supported by the presence of epithelial (cytokeratin-positive) cells in the PB of patients with overt distant metastases years after the removal of the primary tumour. This suggests that tumour cells could break from bone metastases to recirculate and disseminate to secondary tissues (Pantel \& Brakenhoff 2004). This 'two-step' metastasis model could explain why the DTC in patients with overt metastases closely resemble each other genetically (Klein et al. 2002; see 'Genetic alterations in DTC').

\section{Variability of results in DTC analysis}

According to Ring et al. (2004), in studies using antibody-based (cytometric) assays, cells with the characteristics of tumour cells have been shown in the PB of between 0 and $100 \%$ of patients with operable (stages I-IIIa) breast cancer and $3-100 \%$ of 
patients with metastatic disease. Studies with nucleic acid-based techniques have shown cells with the characteristics of tumour cells in the PB of $0-88 \%$ of patients with operable (stages I-IIIa) breast cancer and $0-100 \%$ of patients with metastatic disease. Along the same line, in a survey on a total of more than 3500 stages I-III breast cancer patients, the incidence of DTC in BM detected by ICC ranged from 13 to $43 \%$ (Braun \& Naume 2005). In fact, the detection rate of DTC in BM from non-metastatic breast cancer patients has been reported to be in the range from $0 \%$ (Fetsch et al. 2000) to $100 \%$ (Slade et al. 2005).

The variability of results obtained in DTC detection results from dramatic variations in methodology. Factors that may influence the data include:

(1) Heterogeneity of the studied populations according to the:

(a) Stage. The number of positive patients and the absolute numbers of DTC per patient rise as clinical stage rises (see notably Ben Hsieh et al. 2006).

(b) Interval of time separating surgery from the obtaining of DTC. Surgery may increase the number of breast cancer DTC (from 0 to 8000 cells $/ \mathrm{ml}$ ) in the $\mathrm{PB}$, which persist for varying length of times in different patients (Hu et al. 2003).

(c) Metastase location. The division of populations into those with early and metastatic breast cancer is probably simplistic. Moreover, metastasis sites could be missed when DTC are obtained, leading to a misclassification of the patient in the 'early breast cancer' category.

(2) Sample handling and preparation:

(a) Delay between collection and analysis.

(b) Conditions of sample storage.

(c) Contamination with normal epithelial cells. The introduction of skin cells into a PB sample at the time of venopuncture could lead to falsepositive results. Many investigators advocate that the first few millilitres of sampled PB are discarded to avoid such contamination. It has also been suggested recently that false positivity of SLN could results from iatrogenic displacement and transport of benign epithelial cells in patients with breast carcinoma (Bleiweiss et al. 2006). Clearly, such epithelial cells do not represent metastasis.

(3) Criteria/threshold of positivity:

Number of cells analysed.

Evaluation or not of the apoptotic status of analysed cells.
(4) Analytical and preanalytical (enrichment) techniques (see 'Techniques for DTC detection').

(5) Markers. A number of different markers have been used. They may considerably vary the levels of sensitivity and specificity (see 'Markers for DTC detection').

\section{Techniques for DTC detection}

The methods to identify DTC must distinguish between epithelial and other (mainly haematopoietic) cells. Secondarily, it may be desirable, although not necessarily essential, to distinguish between cancer and normal epithelial cells.

The most 'conventional' technique has been focussed on LN analysis and involves staining of sectioned tissues, previously embedded in paraffin wax, with two dyes, haematoxylin and eosin (H\&E). It is likely that very small amounts of DTC present in the LN cannot be detected by this technique. An increase in sensitivity can be achieved by serial sectioning and histopathologic examination of an extensive number of sections. However, this approach is time consuming which hampers its routine application.

More sensitive approaches have been developed. Also used for LN is immunohistochemistry (IHC), using antibodies that bind to more or less specific breast cancer cell marker(s). IHC is able to detect regions of metastases in $\mathrm{LN}$ undetected by $\mathrm{H} \& \mathrm{E}$ staining (Cote et al. 1999). However, IHC has several drawbacks: it is a labour intensive and time-consuming method, particularly because at least 100000 cells need to be analysed for a reliable assessment of the presence of tumour cells (Silva et al. 2001a). Moreover, IHC requires a trained cytologist to confirm the identity of the stained cells. Most importantly, and although IHC has been previously applied to PB and $\mathrm{BM}$ smears, this technique is unable to make an accurate measurement of the frequently low DTC load within PB and BM (Gilbey et al. 2004).

To identify DTC in PB and BM, the two major approaches involve additional antibody- and nucleic acid-based techniques.

\section{Antibody-based techniques}

Approaches by fluorescence microscopy (FM), ICC and flow cytometry (FC) analysis aim to isolate and enumerate individual tumour cells. ICC is still a gold standard for DTC detection, and most of the available clinical data have been gathered by ICC screening, especially in BM (Zieglschmid et al. 2005). An 
advantage of this approach is that it may allow further characterization of the cells at a molecular level, in terms of expression of key biological markers, such as ERBB2 (ERBB2 gene amplification estimated by FISH analysis) and morphological cell analysis. However, identification of intracellular targets, such as cytokeratins, by antibodies needs cell permeabilization. As a consequence, cell viability is lost, making the important discrimination of dead and viable DTC impossible. Since only viable cells might lead to metastasis, this valuable information cannot be assessed (Zieglschmid et al. 2005).

Like IHC, FM and ICC are labour intensive and time consuming, making these techniques too expensive for routine implementation. When compared with 'conventional', essentially qualitative FM and ICC, FC offers the advantage of a fully automated technique allowing quantitative measurements with high sensitivity, good resolution, speed, reproducibility and statistical reliability.

For breast tumours, the most used targets for antibody-based techniques are the cytokeratins (see 'Markers'). ERBB2, MUC1 and TACSTD1, the two latters being known under a variety of names (see Table 1), have also been used as antibody targets to isolate and/or identify DTC.

A two-colour ELISPOT, an immunological assay based on enzyme-linked immunosorbent assay, has been recently used to detect DTC-secreting cathepsin D (CTSD) and mucin-1 (MUC1) (see Table 1; AlixPanabières et al. 2005).

Antibody-based techniques have limitations. Many of the antibodies directed at epithelial and breast cancer cells are known to also stain haematopoietic cells, including cytokeratins (KRT19), TACSTD1, MUC1 (see Table 1). Non-specific staining of plasma cells can also occur due to alkaline phosphatase reaction against the $\kappa$ and $\lambda$ light chains on the cell surface (Smerage \& Hayes 2006). According to the antibody used, a falsepositive detection rate of $1-3 \%$ can be expected (Zieglschmid et al. 2005). Since tumour and epithelial-specific cell marker antigens are expressed differentially in DTC, the use of a panel of monoclonal antibodies may help to enrich DTC and facilitate their detection, as notably shown by Hager et al. (2005).

\section{Nucleic acid-based techniques}

PCR, either qualitative or quantitative, has been used to identify and characterize DTC through the detection of genetic (allele-specific expression, micro-satellite instability, loss of heterozygosity) and epigenetic alterations (methylation status) that are specifically associated with cancer cells (Sidransky 1997). This includes the search for tumour-associated point mutations in oncogenes or tumour suppressors. This latter PCR approach, however, is complicated by the substantial degree of genetic variability between tumours. For instance, TP53, the gene coding for $\mathrm{p} 53$, is mutated in about $25 \%$ of breast tumours, however, more than 1400 different mutations of this gene have been observed (Lacroix et al. 2006).

Of note, PCR has been used to detect free DNA within plasma. For instance, the analysis of DNA methylation status of specific genes (ESRl, APC, HSD17B4, HICl, RASSF 1A) in serum of breast cancer patients has been shown to be of prognostic value (Müller et al. 2003); The PCR-based measurement of RASSF1A methylation has been used for monitoring efficacy of adjuvant tamoxifen therapy (Fiegl et al. 2005). However, this use of PCR is limited by poor specificity. This is due in part to the high stability of DNA in plasma when compared with mRNA (Silva et al. 2002). As a result, it is unclear whether the free DNA that is amplified from plasma is from DTC present in plasma or if the DNA is being shed from primary tumours, metastatic tumours, or from normal tissue (Ring et al. 2004).

To identify DNA gains and losses in single DTC, the technique of comparative genomic hybridization (CGH) is increasingly used (see notably Klein et al. 1999, Austrup et al. 2000, Schmidt-Kittler et al. 2003, Schardt et al. 2005).

Reverse transcription (RT)-PCR has been used to identify DTC through their expression of epithelial or breast cancer-associated mRNA transcripts. A list of markers that have been evaluated in DTC by RT-PCR is contained in Table 1. RT-PCR is generally more sensitive than antibody-based techniques, but has also been hampered by false positive results in samples from normal volunteers and from patients with haematological malignancies (Ring et al. 2004). These false positives stem from multiple sources, including issues with laboratory technique, primer selection, illegitimate expression of the target genes in normal cells, the presence of pseudogenes, or contamination (see KRT19/CK19 for more details).

When using assays based on RT-PCR for detection of DTC, the balance between sensitivity and specificity must be considered. Normally, specificity decreases with the increase in sensitivity, and vice versa. One way to resolve this dilemma is to examine multiple tumour markers in samples. As mentioned below, multiplex RT-PCR assays have revealed a higher efficacy (in both sensitivity and specificity) in comparison with the 
Table $1 \mathrm{~A}$ list of markers that have been used in mono- or multi-markers assays to detect disseminated tumour cells by antibody (KRT8, KRT18) or nucleic acid-based techniques

\begin{tabular}{|c|c|c|c|c|}
\hline $\begin{array}{l}\text { Marker (gene) } \\
\text { name }\end{array}$ & $\begin{array}{l}\text { Gene } \\
\text { locus }\end{array}$ & $\begin{array}{l}\text { Standard } \\
\text { name }\end{array}$ & $\begin{array}{l}\text { Other frequently-used } \\
\text { names }\end{array}$ & $\begin{array}{l}\text { Reference(s) related to DTC } \\
\text { detection }\end{array}$ \\
\hline ANKRD30A & $10 p 11.21$ & Ankyrin repeat domain $30 \mathrm{~A}$ & $\begin{array}{l}\text { Breast cancer antigen NY-BR-1; } \\
\text { B726P }\end{array}$ & $\begin{array}{c}\text { Backus et al. (2005), Reinholz } \\
\text { et al. (2005), Nissan et al. } \\
\text { (2006), Zach \& Lutz (2006) }\end{array}$ \\
\hline$B 305 D$ & $21 q 11.1-q 11.2$ & Antigen B305D & $\begin{array}{l}\text { B305D, isoform A (B305D-A) } \\
\text { B305D, isoform C (B305D-C) }\end{array}$ & $\begin{array}{l}\text { Backus et al. (2005), Reinholz } \\
\text { et al. (2005), Zach \& Lutz } \\
\text { (2006) }\end{array}$ \\
\hline$C D 44$ & 11p13-pter & Antigen CD44 & Hermes antigen; PGP1 & Gilbey et al. (2004) \\
\hline $\mathrm{CDH} 1$ & $16 q 22.1$ & Cadherin-1 (epithelial) & E-cadherin; Uvomorulin & Harigopal et al. (2005) \\
\hline CEACAM5 & $19 q 13.2$ & $\begin{array}{l}\text { Carcino-embryonic antigen- } \\
\text { related cell adhesion } \\
\text { molecule } 5\end{array}$ & $\begin{array}{l}\text { Carcino-embryonic antigen } \\
\text { (CEA) }\end{array}$ & $\begin{array}{l}\text { Gilbey et al. (2004), Gillanders } \\
\text { et al. }(2004), \text { Mikhitarian } \\
\text { et al. }(2005 a, b)\end{array}$ \\
\hline$C G B$ & $19 q 13.32$ & $\begin{array}{l}\text { Chorionic gonadotrophin, } \beta \\
\text { polypeptide }\end{array}$ & $\begin{array}{l}\beta \text {-Human chorionic gonado- } \\
\text { trophin ( } \beta \text {-HCG) }\end{array}$ & $\begin{array}{l}\text { Gilbey et al. (2004), Ring et al. } \\
\text { (2004), Zach \& Lutz (2006) }\end{array}$ \\
\hline$C T S D$ & $11 \mathrm{p} 15.5$ & Cathepsin-D & & $\begin{array}{l}\text { Alix-Panabières et al. (2005), } \\
\text { Zach \& Lutz (2006) }\end{array}$ \\
\hline CXCR4 & $2 q 21$ & $\begin{array}{l}\text { Chemokine, CXC motif, } \\
\text { receptor } 4\end{array}$ & $\begin{array}{l}\text { Neuropeptide Y receptor Y3 } \\
\text { (NPY3R); Lipopolysacchar- } \\
\text { ide-associated protein } 3 \\
\text { (LAP3); Fusin }\end{array}$ & Alix-Panabières et al. (2005) \\
\hline$E G F R$ & 7p12.3-p12.1 & $\begin{array}{l}\text { Epidermal growth factor } \\
\text { receptor }\end{array}$ & Oncogene ERBB1; c-erbB-1 & $\begin{array}{l}\text { Gilbey et al. (2004), Ring et al. } \\
\text { (2004) }\end{array}$ \\
\hline ERBB2 & $17 q 21.1$ & c-erbB-2 & Her-2 Neu & $\begin{array}{l}\text { Gilbey et al. (2004), Meng } \\
\text { et al. (2004a), Ring et al. } \\
\text { (2004), Backus et al. } \\
\text { (2005), Smirnov et al. } \\
(2005)\end{array}$ \\
\hline GABRP & $5 q 32-q 33$ & $\begin{array}{l}\gamma \text {-Aminobutyric acid type A } \\
\text { receptor pi }(\pi) \text { subunit }\end{array}$ & $\begin{array}{l}\text { GABA receptor } A, \text { pi }(\pi) \text { poly- } \\
\text { peptide }(\text { GABARAP); GABA- } \\
\text { A receptor, pi }(\pi) \text { polypeptide } \\
(\text { GABA } A(\pi))\end{array}$ & $\begin{array}{l}\text { Backus et al. (2005), Reinholz } \\
\text { et al. (2005), Zach \& Lutz } \\
\text { (2006) }\end{array}$ \\
\hline GALNT6 & $12 q 13$ & $\begin{array}{l}\text { UDP- } N \text {-acetyl-D-galactosa- } \\
\text { mine:polypeptide } N \text {-acet- } \\
\text { ylgalactosaminyltransfer- } \\
\text { ase } 6\end{array}$ & $\begin{array}{l}\text { ppGalNac-T(6); } \beta-1-4-N \text {-acetyl- } \\
\text { galactosaminyl-transferase 6; } \\
\text { GalNAc transferase 6; } \\
\text { (GalNAcT6) }\end{array}$ & $\begin{array}{l}\text { Gilbey et al. (2004), Ring et al. } \\
\text { (2004), Freire et al. (2006) }\end{array}$ \\
\hline$K R T 7$ & $12 q 12-q 14$ & Keratin 7 & $\begin{array}{l}\text { Cytokeratin } 7 \text { (CK7); Sarcolectin } \\
\quad(\mathrm{SCL})\end{array}$ & $\begin{array}{l}\text { Ring et al. (2004), Masuda } \\
\text { et al. (2005) }\end{array}$ \\
\hline KRT8 & $12 q 13$ & Keratin 8 & Cytokeratin 8 (CK8) & $\begin{array}{l}\text { Ouellette et al. (2004), Ring } \\
\text { et al. (2004), Mikhitarian } \\
\text { et al. }(2005 a, b)\end{array}$ \\
\hline KRT18 & $12 q 13$ & Keratin 18 & Cytokeratin 18 (CK18) & $\begin{array}{l}\text { Ring et al. (2004), Smirnov } \\
\text { et al. (2005) }\end{array}$ \\
\hline KRT19 & 17q21-q22 & Keratin 19 & Cytokeratin 19 (CK19) & $\begin{array}{l}\text { Gilbey et al. (2004), Gillanders } \\
\text { et al. (2004), Ring et al. } \\
\text { (2004, 2005), Weigelt et al. } \\
\text { (2004), Backus et al. } \\
\text { (2005), Mikhitarian et al. } \\
\text { (2005a,b), Smirnov et al. } \\
\text { (2005), Brown et al. (2006), } \\
\text { Nissan et al. (2006), Zach \& } \\
\text { Lutz (2006) }\end{array}$ \\
\hline KRT20 & $17 q 21.2$ & Keratin 20 & Cytokeratin 20 (CK20) & Gilbey et al. (2004) \\
\hline $\begin{array}{l}\text { MAGE-A sub- } \\
\text { types }\end{array}$ & Xq28 & $\begin{array}{l}\text { Melanoma antigen family A } \\
\text { subtypes }\end{array}$ & Mage & Kwon et al. (2005) \\
\hline MAGEA3 & Xq28 & $\begin{array}{l}\text { Melanoma antigen family A, } \\
\quad 3\end{array}$ & Mage3 & $\begin{array}{l}\text { Gilbey et al. (2004), Ring et al. } \\
\text { (2004), Abdul-Rasool et al. } \\
\text { (2006) }\end{array}$ \\
\hline
\end{tabular}

(continued) 


\begin{tabular}{|c|c|c|c|c|}
\hline $\begin{array}{l}\text { Marker (gene) } \\
\text { name }\end{array}$ & $\begin{array}{l}\text { Gene } \\
\text { locus }\end{array}$ & $\begin{array}{l}\text { Standard } \\
\text { name }\end{array}$ & $\begin{array}{l}\text { Other frequently-used } \\
\text { names }\end{array}$ & $\begin{array}{l}\text { Reference(s) related to DTC } \\
\text { detection }\end{array}$ \\
\hline$M E T$ & $7 q 31$ & Protooncogene met & $\begin{array}{l}\text { Hepatocyte growth factor } \\
\text { receptor (HGFR); Renal cell } \\
\text { carcinoma, papillary } 2 \\
\text { (RCCP2) }\end{array}$ & $\begin{array}{l}\text { Gilbey et al. (2004), Ring et al. } \\
\text { (2004) }\end{array}$ \\
\hline MUC1 & $1 q 21$ & Mucin-1, transmembrane & $\begin{array}{l}\text { Carcinoma antigen } 15.3 \\
\text { (CA15.3); Carcinoma antigen } \\
27.29 \text { (CA27.29); CD227 } \\
\text { antigen; Episialin; Epithelial } \\
\text { membrane antigen (EMA); } \\
\text { Polymorphic epithelial mucin } \\
\text { (PEM); Peanut-reactive } \\
\text { urinary mucin (PUM); } \\
\text { Tumour-associated glyco- } \\
\text { protein } 12 \text { (TAG12) }\end{array}$ & $\begin{array}{l}\text { Gilbey et al. (2004), Gillanders } \\
\text { et al. (2004), Ring et al. } \\
\text { (2004), Backus et al. } \\
\text { (2005), Schindlbeck et al. } \\
\text { (2005), Zach \& Lutz (2006) }\end{array}$ \\
\hline PIP & $7 q 32-q 36$ & Prolactin-induced protein & $\begin{array}{l}\text { Gross cystic disease fluid } \\
\text { protein (GCDFP-15) }\end{array}$ & $\begin{array}{l}\text { Gillanders et al. (2004), Ring } \\
\text { et al. (2004), Backus et al. } \\
\text { (2005), Mikhitarian et al. } \\
\text { (2005a,b), Smirnov et al. } \\
\text { (2005), Zach \& Lutz (2006) }\end{array}$ \\
\hline PLAUR & $19 q 13$ & $\begin{array}{l}\text { Plasminogen activator } \\
\text { receptor, urokinase-type }\end{array}$ & $\begin{array}{l}\text { Urokinase receptor (UPAR); } \\
\text { CD87 antigen }\end{array}$ & Pierga et al. (2005) \\
\hline PTHLH & $12 \mathrm{p} 12.1-\mathrm{p} 11.2$ & $\begin{array}{l}\text { Parathyroid hormone-like } \\
\text { hormone }\end{array}$ & $\begin{array}{l}\text { PTHrP (parathyroid hormone- } \\
\text { related protein) }\end{array}$ & Gilbey et al. (2004) \\
\hline SBEM & $12 q 13.2$ & $\begin{array}{l}\text { Small breast epithelial } \\
\text { mucin }\end{array}$ & BS106, B511S & $\begin{array}{l}\text { Weigelt et al. (2004), Backus } \\
\text { et al. (2005), Brown et al. } \\
\text { (2006) }\end{array}$ \\
\hline SCGB1D2 & $11 q 12.2$ & $\begin{array}{l}\text { Secretoglobin family } 1 \mathrm{D} \\
\text { member } 2\end{array}$ & $\begin{array}{l}\text { (Prostatein-like) Lipophilin B } \\
\text { (LPB, LPHB); Antigen BU101 }\end{array}$ & $\begin{array}{l}\text { Mikhitarian et al. }(2005 a, b) \text {, } \\
\text { Brown et al. (2006) }\end{array}$ \\
\hline$S C G B 2 A 1$ & $11 q 12.2$ & $\begin{array}{l}\text { Secretoglobin family } 2 \mathrm{~A} \text {, } \\
\text { member } 1\end{array}$ & $\begin{array}{l}\text { Mammaglobin } 2 \text { (MGB2); } \\
\text { Mammaglobin B (MGBB); } \\
\text { Lacryglobin (LGB) Lipophilin } \\
\text { C (LPC, LPHC) }\end{array}$ & $\begin{array}{l}\text { Aihara et al. (1999), Gillanders } \\
\text { et al. (2004), Ouellette et al. } \\
\text { (2004), Mikhitarian et al. } \\
\text { (2005a,b), Smirnov et al. } \\
\text { (2005), Nissan et al. (2006) }\end{array}$ \\
\hline$S C G B 2 A 2$ & $11 q 12.2$ & $\begin{array}{l}\text { Secretoglobin family } 2 \mathrm{~A} \text {, } \\
\text { member } 2\end{array}$ & $\begin{array}{l}\text { Mammaglobin (MGB); Mamma- } \\
\text { globin } 1 \text { (MGB1); } \\
\text { Mammaglobin A (MGBA) }\end{array}$ & $\begin{array}{l}\text { Gilbey et al. (2004), Gillanders } \\
\text { et al. (2004), Janku et al. } \\
\text { (2004), Ouellette et al. } \\
\text { (2004), Ring et al. (2004, } \\
\text { 2005), Weigelt et al. (2004), } \\
\text { Backus et al., (2005), } \\
\text { Mikhitarian et al. (2005a,b), } \\
\text { Reinholz et al. (2005), } \\
\text { Smirnov et al. (2005), } \\
\text { Abdul-Rasool et al. (2006), } \\
\text { Brown et al. (2006), Zach \& } \\
\text { Lutz (2006) }\end{array}$ \\
\hline SERPINB5 & $18 q 21.3$ & $\begin{array}{l}\text { Serine (or cysteine) } \\
\text { proteinase inhibitor, clade } \\
\text { B (ovalbumin), member } 5\end{array}$ & $\begin{array}{l}\text { Mammary serine protease } \\
\text { inhibitor (Maspin) }\end{array}$ & $\begin{array}{l}\text { Gilbey et al. (2004), Ring et al. } \\
\text { (2004), Zach \& Lutz (2006) }\end{array}$ \\
\hline SPDEF & $6 p 21.3$ & $\begin{array}{l}\text { Sterile alpha motif pointed } \\
\text { domain-containing ets } \\
\text { transcription factor }\end{array}$ & $\begin{array}{l}\text { Prostate epithelium-specific Ets } \\
\text { transcription factor (PDEF) }\end{array}$ & $\begin{array}{l}\text { Gillanders et al. (2004), } \\
\text { Backus et al. (2005), Mikhi- } \\
\text { tarian et al. }(2005 a, b)\end{array}$ \\
\hline
\end{tabular}

(continued) 


\begin{tabular}{|c|c|c|c|c|}
\hline $\begin{array}{l}\text { Marker (gene) } \\
\text { name }\end{array}$ & $\begin{array}{l}\text { Gene } \\
\text { locus }\end{array}$ & $\begin{array}{l}\text { Standard } \\
\text { name }\end{array}$ & $\begin{array}{l}\text { Other frequently-used } \\
\text { names }\end{array}$ & $\begin{array}{l}\text { Reference(s) related to DTC } \\
\text { detection }\end{array}$ \\
\hline TACSTD1 & $2 p 21$ & $\begin{array}{l}\text { Tumour-associated calcium } \\
\text { signal transducer } 1\end{array}$ & $\begin{array}{l}\text { Colorectal carcinoma antigen } \\
\text { CO17-1A; Epithelial } \\
\text { glycoprotein } 2 \text { (EGP2); } \\
\text { Epithelial glycoprotein } 40 \text { kDa } \\
\text { (EGP40); Epithelial cell } \\
\text { adhesion molecule (EpCAM); } \\
\text { Epithelial-specific antigen } \\
\text { (ESA); Gastrointestinal } \\
\text { tumour-associated antigen } \\
\text { 733-2 (GA733-2); KS1/4 anti- } \\
\text { gen; KSA antigen; Membrane } \\
\text { component, chromosome 4, } \\
\text { surface marker } 1 \text { (M4S1); } \\
\text { MK-1 antigen; MIC18 antigen; } \\
\text { TROP-1 antigen }\end{array}$ & $\begin{array}{l}\text { Gilbey et al. (2004), Ring et al. } \\
\text { (2004), Weigelt et al. } \\
\text { (2004), Mikhitarian et al. } \\
(2005 a, b), \text { Smirnov et al. } \\
(2005)\end{array}$ \\
\hline TERT & $5 p 15.33$ & $\begin{array}{l}\text { Telomerase reverse } \\
\text { transcriptase }\end{array}$ & Telomerase catalytic subunit & Ring et al. (2004) \\
\hline TFF1 & $21 q 22.3$ & Trefoil factor 1 & $\begin{array}{l}\text { Breast cancer oestrogen-indu- } \\
\text { cible sequence (BCEI); } \\
\text { Gastrointestinal trefoil protein } \\
\text { (GTF); pS2 protein }\end{array}$ & $\begin{array}{l}\text { Ring et al. (2004), Weigelt et } \\
\text { al. (2004), Mikhitarian et al. } \\
(2005 a, b), \text { Smirnov et al. } \\
(2005)\end{array}$ \\
\hline TFF3 & $21 q 22.3$ & Trefoil factor 3 & $\begin{array}{l}\text { Intestinal trefoil factor (ITF); } \\
\text { p1.B }\end{array}$ & $\begin{array}{l}\text { Ring et al. (2004), Weigelt et } \\
\text { al. (2004), Mikhitarian et al. } \\
(2005 a, b), \text { Smirnov et al. } \\
(2005)\end{array}$ \\
\hline
\end{tabular}

assessment of single markers. To improve the reliability, especially the specificity of RT-PCR assays, quantitative RT-PCR (qRT-PCR) may be used. In addition, qualitative marker information, qRT-PCR uses cut-off values of marker transcript numbers, below which transcripts can be considered as tumour cell derived. Moreover, when compared with 'conventional' RT-PCR, qRT-PCR relies not only on primers, but also on internal probes that specifically hybridize to the amplified sequences. In addition, due to the continuous measurement of the amplified signal, false-positive results, which could produce an abnormally shaped, non-linear amplification curve could be easily identified and removed (Zieglschmid et al. 2005).

Variations of the RT-PCR technique, such as nested RT-PCR and competitive nested RT-PCR, have also been used (for instance, see the review of Gilbey et al. 2004).

Fluorescence in situ hybridization (FISH) allows the detection of gene amplifications, for instance ERBB2 amplification in breast cancer. FISH has been used to analyse genetic aberrations in DTC in BM. Considering the importance of ERBB2 as a recent target for successful antibody-based therapy, the use of FISH to detect ERBB2 amplification in DTC appears promising (Meng et al. 2004a).

\section{Preanalytical DTC enrichment techniques}

Even in metastatic patients, the number of DTC in PB or in $\mathrm{BM}$ is low when compared with the surrounding normal cells. When present in PB, DTC are generally found at a frequency of one cell per $1 \times 10^{5-7} \mathrm{~PB}$ mononuclear cells (PBMC; Ross et al. 1993) or in number $<10 \mathrm{DTC} / \mathrm{ml}$. The frequency of DTC in cytological BM preparation from cancer patients has been estimated to be in the range of $10^{-5}-10^{-6}$ (Pantel et al. 1999). For most markers used by nucleic acid-based techniques, the sensitivity (one cancer cell detected among $10^{7} \mathrm{PBMC}$, in most cases) could have been overestimated when it was evaluated by in vitro spiking experiments using chosen cancer cell lines overexpressing the selected markers. Metastatic tumour cells in vivo, however, might not (or at significantly lower level) express the tested markers due to tumour heterogeneity. In addition, sequential sampling might be necessary to improve tumour cell detection since shedding into the circulation could occur intermittently.

These observations led to the development of specific methods to enrich (up to 10000 times) the DTC population before their differentiation from other $\mathrm{PB}$ or BM components. DTC enrichment is usually performed through the use of density gradients 
(Ficoll/Hypaque, OncoQuick...), porous membranes, or immunomagnetic selection (IMS) techniques (using magnetic affinity cell sorting or magnetic beads). Density gradients allow the isolation of mononuclear cells, which are believed to contain the DTC fraction. However, tumour cell loss may occur, which might be partly due to the fact that DTC may also sediment in the granulocyte fraction (Zehentner 2002a, Gaforio et al. 2003). Porous membranes with pore sizes chosen such that smaller leukocytes pass through are also available for DTC enrichment. IMS techniques use specific antibodies, linked to small paramagnetic beads. IMS may be positive when the antibodies used target epithelial or breast cancer antigens, or negative when it targets common cell surface antigens expressed on leukocytes, such as CD45. The loss of tumour cells due to the absence of targeted capture antigens is minimized using negative selection approaches. However, the available protocols do not completely eradicate the presence of haematopoietic cells. Therefore, it is crucial for the development of molecular diagnostic assays to choose nucleic acid markers that are not expressed in normal haematological tissue. The question whether positive or negative IMS results in higher tumour cell recovery is controversial, as some groups reported higher tumour cell detection by positive IMS yet others found the opposite to be the case (Zieglschmid et al. 2005).

Immunomagnetic enrichment techniques can be incorporated into semi-automated laboratory devices, as shown recently for the enumeration of DTC in patients with advanced disease (Cristofanilli et al. 2005a).

\section{Markers for DTC detection}

During the last years, the number of single markers that have been evaluated for DTC detection, mainly by nucleic acid-based techniques, has considerably increased (see Table 1). For a detailed description of these studies, the reader is invited to consult the recent reviews of Gilbey et al. 2004, Ring et al. 2004, 2005, Zach \& Lutz 2006. In the present paper, the same name will be used for the gene and the corresponding protein. For instance, despite the fact that the terms NY-BR-1 and $\mathrm{B} 726 \mathrm{P}$ are encountered in the literature, the name of the corresponding gene, ANKRD30A, will also preferentially be used to cite the protein. SCGB2A2 will be used instead of mammaglobin, ESR1 instead of oestrogen receptor- $\alpha(E R \alpha)$, etc.

An ideal marker should be universally, but uniquely expressed on all breast cancer cells. It should be easily detectable, with little variance and bear clinical relevance. Since no single-specific marker that meets these criteria has been identified, attempts are now made to develop assays with multiple tumour markers, of which some are preferably highly specific to breast tissue or breast tumours. The aim is to avoid both false-positive (detection of non-tumour cells, due to the fact that the majority of potential markers have some baseline expression in normal tissues) and falsenegative (non-detection of tumour cells, due to the use of high-threshold levels for positivity) cases.

Multi-marker assays have been used by various investigators (see Table 2 and the reviews of Gilbey et al. 2004, Ring et al. 2004, 2005, Zach \& Lutz 2006) and have revealed a higher efficacy (sensitivity and specificity) in comparison with the assessment of single markers. A detailed and comparative analysis of these and more recent studies, including studied material (LN, PB or BM), amplification methods, RT-PCR cycling conditions, sensitivity, specificity, single or combined positivity in samples, would deserve a specific article and will thus not be performed here.

\section{Markers with low breast (cancer) specificity \\ Cytokeratins (KRTs)}

Regarding epithelial tumours, the cytoskeleton components KRTs have become the markers of choice for DTC detection. They belong to a large multigene family of more than 30 known members. They are expressed at various levels and compositions in all epithelial tumours, but rarely in other tissues. For antibodybased studies, most researchers use a combination of several monoclonal antibodies that recognize various cytokeratin antigens, or a broad-spectrum anti-cytokeratin monoclonal antibody that recognizes a single epitope that is common to most cytokeratins (for more information, see the review papers of Pantel \& Brakenhoff (2004) and Ring et al. (2004)).

For nucleic acid-based studies, cytokeratin 19 (KRT19) and to a lesser extent, cytokeratin 20 (KRT20) have been frequently used as markers.

\section{KRT19, an illustration of the potential sources of false positivity in DTC detection}

Due to its high sensitivity, KRT19 is the most used marker for the detection of DTC in breast cancer patients (Gilbey et al. 2004, Ring et al. 2004, Zach \& Lutz 2006). Depending on the assays, KRT19 has been shown to be both a specific and a non-specific marker. In fact, KRT19 is an excellent candidate to illustrate the 
Table 2 An overview of markers used in multi-marker studies

\begin{tabular}{|c|c|}
\hline Markers & Reference of the study \\
\hline KRT19, SERPINB5 & Luppi et al. (1998) \\
\hline CEACAM5, KRT19, KRT20, MUC1, TACSTD1 & Bostick et al. (1998) \\
\hline CD44, KRT19, MUC1 & Eltahir et al. (1998) \\
\hline CEACAM5, KRT19, SERPINB5 & Lopez-Guerrero et al. (1999) \\
\hline CEACAM5, KRT19, MUC1 & Goeminne et al. (1999) \\
\hline KRT19, EGFR, SCGB2A2 & Grunewald et al. (2000) \\
\hline CEACAM5, KRT19, MUC1 & Berois et al. (2000) \\
\hline CEACAM5, EGFR, KRT19, KRT20, MUC1, SCGB2A2, SERPINB5 & Corradini et al. (2001) \\
\hline ERBB2, SCGB2A2, SERPINB5 & Leone et al. (2001) \\
\hline KRT19, SCGB2A2 & Silva et al. (2001b) \\
\hline CGB, KRT19, KRT20 & Hu \& Chow (2001) \\
\hline CEACAM5, ERBB2, KRT19, MUC1, PIP, SCGB2A1, SCGB2A2 & Mitas et al. (2001) \\
\hline CGB, GALNT6, MAGEA3, MET & Taback et al. (2001) \\
\hline KRT19, TACSTD1, TFF1, TFF3 & Bosma et al. (2002) \\
\hline EGFR, KRT19, KRT20 & Gradilone et al. (2003) \\
\hline KRT19, MUC1, PIP, SCGB2A1, SCGB2A2, SPDEF & Baker et al. (2003) \\
\hline ANKRD30A, B305D, GABRP, SCGB2A2 & Zehentner et al. (2004) \\
\hline EGFR, KRT19, SBEM, SCGB2A2, TACSTD1, TFF1, TFF3 & Weigelt et al. (2004) \\
\hline CEACAM5, KRT19, MUC1, PIP, SCGB2A1, SCGB2A2, SPDEF & Gillanders et al. (2004) \\
\hline KRT19, SCGB2A2, SERPINB5 & Ferrucci et al. (2004) \\
\hline CGB, KRT19, SCGB2A2 & Fabisiewicz et al. (2004) \\
\hline ANKRD30A, B305D, GABRP, KRT19, SCGB2A2 & Reinholz et al. (2005) \\
\hline KRT19, PIP, SCGB2A2 & Ring et al. (2005) \\
\hline KRT19, SBEM, SCGB1D2, SCGB2A2 & Brown et al. (2006) \\
\hline ANKRD30A, KRT19, SCGB2A1 & Nissan et al. (2006) \\
\hline SCGB2A1, SERPINB5 & Mercatali et al. (2006) \\
\hline ERBB2, KRT19, TACSTD1, TFF1, TFF3 & Quintela-Fandino et al. (2006) \\
\hline
\end{tabular}

potential sources of false positivity in RT-PCR studies: illegitimate transcription, haematological disorders, the presence of pseudogenes, sample contamination.

Illegitimate transcription. This term describes the expression in normal tissues of small amounts of mRNA by genes that have no real physiological role in these cells. It can be expected that every promoter could be activated by ubiquitous transcription factors, which leads to an estimated expression level of one tumour marker gene transcript in 500-1000 nontumour cells (Zieglschmid et al. 2005).

Haematological disorders. KRT19 expression can be induced in PB by cytokines and growth factors, which circulate at higher concentrations in inflammatory conditions and neutropenia (Ring et al. 2004). As a consequence, false-positive results are more likely under these circumstances.

The presence of pseudogenes. Two KRT19 pseudogenes, KRT19a and KRT19b (Savtchenko et al. 1988, Ruud et al. 1999), have been identified, which have significant sequence homology to KRT19 mRNA. Subsequently, attempts to detect the expression of the authentic KRT19 may result in the detection of either or both of these pseudogenes. To avoid pseudogene amplification, it is recommended to carefully design the primers used for RT-PCR analysis.

Contamination. It has been suggested that $\mathrm{PB}$ sampling for subsequent analysis could introduce contaminating epithelial cells expressing the KRT19 mRNA into the blood sample. Potential contamination could be minimized or prevented by discarding the first sample of blood taken.

In conclusion, KRT19 appears to be a very sensitive tumour marker, whose use, however, is often hampered by low specificity. It is helpful in detecting disseminated epithelial cells, but is not a true breast cancer marker.

\section{KRT20}

KRT20 is found in breast cancer cells (Bostick et al. 1998, Corradini et al. 2001, Hu \& Chow 2001). However, its expression is less related to breast tissue and more related to gastric and intestinal epithelium, urothelium and Merkel cells (Zieglschmid et al. 2005). Moreover, KRT20 expression has been found in granulocytes (Jung et al. 1999). Due to its lower specificity, when compared with KRT19, the use of KRT20 is not recommended in breast cancer patients. 


\section{KRT8 and KRT18}

KRT8 and KRT18 have been rarely used for DTC detection. In fact, the expression patterns of these epithelial cytokines are very similar to that of KRT19 and they are not expected to provide more specificity than this latter. Of note, KRT8, KRT18 and KRT19 are expressed in the breast epithelium, but at higher levels in the luminal than in the basal component. In view of recent observations that breast tumours may be classified into subtypes, or classes (see 'recent data on breast cancer classification and progression'), including 'luminal epithelial-like' and 'basal epithelial-like' classes, one can speculate that these cytokeratins will be less easily detected in DTC originating from basallike tumours.

\section{CEACAM5}

Widely known as CEA, it functions in several biological roles, including cell-cell adhesion. It is one of the most widely expressed markers in breast as well as in various other cancer cells (Gilbey et al. 2004, Ring et al. 2004, Zach \& Lutz 2006). Therefore, it suffers from low specificity, as also observed with KRT19, and can similarly be induced in PB by cytokines and growth factors (Goeminne et al. 1999, Ring et al. 2004).

\section{TACSTD1}

This epithelial cell-cell adhesion protein is known under a variety of names (Table 1), of which GA733-2 and EpCAM are the most frequently used. Ubiquitously expressed on the surface of epithelial cells, it has been frequently used as target for positive IMS to enrich DTC for RT-PCR analysis (Zieglschmid et al. 2005). Monoclonal antibodies against this antigen have been extensively developed for diagnostic, but also therapeutic, approaches. Although highly sensitive for epithelial malignancies, including breast cancer, its use is, however, hampered by the fact that it is expressed in low amounts in PB cells (de Graaf et al. 1997, Bostick et al. 1998, Zhong et al. 1999).

\section{MUC1}

Mucin-1 is a very large, polymorphic and heavily glycosylated mucin. The role of mucins is primarily one of the hydrating and lubricating epithelial linings, but these proteins have also been implicated in modulating both growth factor signalling and cell adhesion. In line with this latter role, it has been suggested that MUC1 expression at the surface of tumour cells could decrease cell adhesion and favour dissemination (Ligtenberg et al. 1992). On the other hand, MUC1 could play a role in the initial attachment of breast tumour cells to tissue at distant sites, facilitating establishment of metastatic sites (Ciborowski \& Finn 2002).

Widely expressed in normal epithelial tissues, MUC1 is notably present on the apical surfaces of breast, bronchial, pancreatic, uterine, salivary, intestinal and other glandular tissue cells. Like TACSTD1, MUC1 has been frequently used as target for positive IMS to enrich DTC for RT-PCR analysis (Zieglschmid et al. 2005). Several studies have reported the expression of MUC1 in a significant proportion of healthy blood donors. Indeed, MUC1 expression has been consistently found in PB cells (Zieglschmid et al. 2005). Despite this low specificity, the evaluation of MUC1 expression in DTC is supported by the increasing interest for MUC1-based immunotherapy (Emens et al. 2005).

Although MUC1 is expressed in a majority of breast tumours, its overexpression has been associated with a lower grade and a higher ER-positive phenotype (see notably Rakha et al. 2005).

\section{EGFR}

A series of RT-PCR-based mono- or multi-marker studies have evaluated the pertinence of this growth factor receptor for DTC detection (Leitzel et al. 1998, De Luca et al. 2000, Grunewald et al. 2000, Corradini et al. 2001, Gradilone et al. 2003, Weigelt et al. 2004). $E G F R$ appears as more specific, but less sensitive than KRT19. Unfortunately, it has also been found occasionally in the PB of healthy donors (Zieglschmid et al. 2005). Moreover, Weigelt et al. (2004) have found that the median expression of EGFR was higher in normal ALN than in DTC positive ALN! Of note, EGFRvIII, a cancer-specific EGFR variant, has been recently used to detect DTC in breast cancer patients. The mutant was detected in the peripheral blood in $30 \%$ of 33 low risk, early-stage patients, $56 \%$ of 18 patients selected for neoadjuvant chemotherapy, $63.6 \%$ of 11 patients with disseminated disease and, notably, 0 of 40 control women (Silva et al. 2006).

\section{ERBB2}

Involved in growth factor signal transduction, ERBB2 plays a major role in breast tumour biology. However, it is not breast-specific (Leone et al. 2001, Mitas et al. 2001) and weak ERBB2 expression has been found in the PB of healthy women in several studies (Zieglschmid et al. 2005). However, it is overexpressed in $20-35 \%$ of breast cancer patients, mostly as a consequence of gene amplification, and this predicts for reduced survival. Moreover, in patients 
with breast cancer, ERBB2 overexpression by DTC in the BM predicts poor clinical outcome (Braun et al. 2001b). This, as well as the increasing use of ERBB2 as target for immunotherapy (trastuzumab; Emens et al. 2005), supports its evaluation in DTC, at both the mRNA (RT-PCR) and the DNA (FISH) levels.

\section{Markers with high breast (cancer) specificity}

\section{The search for new markers}

Using molecular biology techniques, or combinations of techniques, various groups have identified markers specifically expressed in breast and/or breast cancer tissue or cells, when compared with normal PB, BM, or other human tissues.

For instance, genes abundantly expressed in breast cancer tissue, but absent in normal PB and BM have been identified by serial analysis of gene expression (SAGE). By order of decreasing SAGE tag frequency, these genes are SBEM, LACRT, TFF3, COL1A1, MGP, KRT8, MUC1, KRT7, CLECSF1, IL6ST, APOC1, SCGB2A2, TFF 1, TM4SF1, C6, KRT19 (Bosma et al. 2002).

A series of genes coding for secreted proteins overexpressed in breast cancer tissue when compared with corresponding normal tissue and/or other (colon, gastric, kidney, liver, lung, ovary, pancreas, prostate) normal tissues were identified by a combination of annotation/protein sequence analysis, transcript profiling, immunohistochemistry and immunoassay: HAPLN1, GFRA, SCGB1D2, CXCL10, CXCL11, COL11A1, E2F3, TRMT1, CHST2, SERHL2, ZNF324, SCGB2A2, COX6C and SCGB2A1 (Welsh et al. 2003).

Gene expression profiling was used to build a site of origin classifier in order to determine the origin of cancer of unknown primary. From an analysis of 229 primary and metastatic tumours representing 14 tumour types (breast - 34 samples, colorectal, gastric, melanoma, mesothelioma, ovarian, pancreas, prostate, renal, testicular, squamous cell carcinoma, uterine, lung), an 'optimal' list of 79 site-specific markers was defined. Genes related to breast-specificity were ACADSB, CCNG2, ESR1, EFHD1, GATA3, SLC39A6, MYB, SCYL3, PIK3R3, PIP, PRLR, RABEP1, TRPS1 and VAV3. Two of them, GATA3 and $P I P$, were identified that seemed to be strongly and relatively uniformly expressed across the range of breast tumours (Tothill et al. 2005).

Smirnov et al. (2005) obtained PB containing $\geq 100$ DTC from one metastatic colorectal, one metastatic prostate and one metastatic breast cancer patient. In a first step, global gene expression analysis was performed on these samples and a list of cancerspecific DTC genes was obtained. Among genes distinguishing between tumour (colorectal and prostate and breast) and control patients were KRT18, KRT19, TACSTD1, TACSTD2, AGR2, TFF1 and TFF3, all genes known to be associated to the epithelial cell phenotype. Fifty-three genes distinguishing between breast tumour and controls were identified, including ESR1 and ERBB2. In a second step, PB samples immunomagnetically enriched for DTC from 74 metastatic patients (30 colorectal, 31 prostate, 13 metastatic breast cancer patients and 50 normal donors were used to confirm the DTC-specific expression of selected genes by realtime RT-PCR). The genes most restricted to breast cancer patients, when compared with normal donors, colorectal cancer and prostate cancer patients were SCGB2A1, SCGB2A2 and PIP. Two additional genes, S100A14 and S100A16, were restricted to breast and colon cancers. Of note, two genes, KRT19 and AGR2, were expressed in the majority of metastatic samples (colorectal and prostate and breast) and not in the control individuals. This confirms the interest of KRT19 as an epithelial tumour cell marker. To date, AGR2 expression has been less frequently examined (Smirnov et al. 2005).

Mikhitarian et al. (2005a) isolated RNA from a highly metastatic SCGB2A2-overexpressing ALN (only one sample). It was diluted into a pool of normal LN RNA at various ratios. Gene expression (microarray) analysis was performed and candidate breast cancer-associated genes were then selected based on three criteria: (a) absence of expression in a pool of four normal LN; (b) a high fluorescence signal on microarray and (c) a fluorescence signal also present in the 1:50 dilution. The 34 genes identified by criteria (a), (b) and (c) were sorted by relative intensity of signal in the metastatic ALN. The 'top15' genes were SCGB2A2, TFF1, TFF3, KRT19, SCGB1D2, S100P, FOS, SERPINA3, ESR1, TACSTD2, JUN, PGDS, KRT8, AFP. Of note, other genes used for molecular detection of micro-metastatic disease, such as PIP, SPDEF, TACSTD1, CEACAM5 and SCGB2A1, were not present among the top15, although their signal was observed in metastatic ALN. Real-time RT-PCR analysis of pathology-negative ALN $(n=72)$ showed that of PIP, SCGB2A2, SPDEF, TACSTD1 and TFF1, SCGB2A2 and TFF1 had the highest apparent sensitivity for the detection of micro-metastatic breast cancer (Mikhitarian et al. 2005a). 
In a micro-array approach, Backus et al. (2005) analysed RNA from samples covering normal, benign and cancerous tissues from breast, colon, lung, ovarian, prostate and peripheral blood leukocytes from healthy donors. By a combination of this micro-array testing and database/literature searching, a series of candidate breast tissue-specific markers and candidate breast cancer status markers were identified. These potential markers were then submitted to an additional multiuse selection process: some markers were excluded for one of the following reasons: (1) their expression level in white blood cells was too high; (2) their expression in breast cancer was too low and (3) their expression in lung, colon and ovarian cancers was too high. The authors finally obtained 14 markers, of which seven, ANKRD30A, GABRP, KRT19, OR4K11P, PIP, SCGB2A2 and SPDEF, were further selected the others were CEACAM6, ERBB2, MUC1, S100A7, S100A14, SBEM and TNNT1). The utility of these markers for identifying clinically actionable metastases in LN was assessed through RT-PCR analysis of SLN from 254 breast cancer patients. The investigators identified an optimal two gene-expression (KRT19 and SCGB2A2) marker set for detection of the actionable metastasis in breast SLN (Backus et al. 2005).

\section{A series of markers with high breast (cancer) specificity}

It is not possible to give here a detailed description of all the markers for which high breast (cancer) specificity has been reported. However, some of these markers emerge, since their specificity has been repeatedly underlined.

\section{SCGB2A2}

No breast cancer marker has been shown to be never expressed in healthy volunteers, but some markers are rarely found in controls. SCGB2A2 (Watson \& Fleming 1996), widely known as mammaglobin, is one of these markers. It is a member of the secretoglobin superfamily (Klug et al. 2000), a group of small, secretory, rarely glycosylated, dimeric proteins mainly expressed in mucosal tissues, and that could be involved in signalling, the immune response, chemotaxis (Brown et al. 2006) and, possibly, as a carrier for steroid hormones in humans.

SCGB2A2 has become a quasi standard in breast DTC detection by RT-PCR-based methods, being the most widely studied marker after KRT19. It has been used to detect DTC in LN, PB, BM, and even in malignant effusions.
SCGB2A2 expression has been detected, rarely and in low levels, in various normal tissues. This could limit its potential use as an immunotherapeutic target (Manna et al. 2003, Jaramillo et al. 2004, Narayanan et al. 2004, Viehl et al. 2005), due to concerns about autoimmune toxicity. Zafrakas et al. (2006a) have recently found an abundant SCGB2A2 expression in malignant and normal tissues of the breast and in the female genital tract, namely the cervix, uterus and ovary, while lower expression levels were rarely found in other tumours and normal tissues (Zafrakas et al. 2006a). These observations might extend the diagnostic potential of SCGB2A2 to the detection of DTC from gynaecologic malignancies.

While SCGB2A2 is considerably more breast cancerspecific than KRT19, it is less 'universal' among these tumours. Indeed, SCGB2A2 expression level is highly variable in breast tumours, some of them showing no expression at all. SCGB2A2 expression, evaluated at mRNA or protein level, has been reported in $61-93 \%$ of primary and/or metastatic breast cancer biopsies (Min et al. 1998, Watson et al. 1999, Houghton et al. 2001, O'Brien et al. 2002, 2005, Han et al. 2003, Span et al. 2004). By examining SCGB2A2 gene expression levels in 11 BCC lines, BT-474, Evsa-T, Hs578T, IBEP-1, IBEP-2, IBEP-3 (Siwek et al. 1998), KPL-1, MCF-7, MDA-MB-231, MDA-MB-453, T-47D, by micro-array and RT-PCR, we have found elevated SCGB2A2 mRNA level only in Evsa-T BCC, while mild expression was observed in BT-474 BCC (de Longueville et al. 2005). Of note, most of these BCC lines are of metastatic origin (Siwek et al. 1998, Lacroix \& Leclercq 2004a,b).

The function of SCGB2A2 in normal breast and its possible role in breast cancer aetiology are unknown. Attempts have been made to find associations between SCGB2A2 expression and various tumour features. High SCGB2A2 expression has been associated with low-grade, steroid receptors-positive tumours from postmenopausal patients (Miksicek et al. 2002, Guan et al. 2003, Span et al. 2004). In accordance, other investigators have found an association with clinical and biological features defining a less aggressive phenotype (Núñez-Villar et al. 2003). According to Roncella et al. (2006), the lack of SCGB2A2 expression is restricted to the breast tumours with high (G3) grade. O'Brien et al. (2005) have shown that in breast tissue, SCGB2A2 exists in two main forms migrating with approximate molecular mass of 18 and $25 \mathrm{kDa}$. The high molecular weight form correlates positively with hormone receptors and negatively with tumour grade and proliferation rate (O'Brien et al. 2005). 
In conclusion, SCGB2A2 has currently the highest diagnostic accuracy for the detection of metastatic breast cancer. However, although tissue specificity is the most important factor for a marker for circulating cells, sensitivity may fail. Unfortunately, the most aggressive, steroid receptor-negative, high-grade breast tumours and their corresponding DTC are likely to escape detection using SCGB2A2 as marker.

\section{SCGB2A1}

SCGB2A1 is a protein far more similar to SCGB2A2 than is to other proteins, including the other members of the secretoglobin superfamily. In breast tumours, SCGB2A1 exhibits a pattern of expression similar to that of SCGB2A2 (Becker et al. 1998). In breast cancer cell lines, SCGB2A1 is highly expressed in MDA-MB-415 BCC, as also observed for SCGB2A2 (Becker et al. 1998).

$S C G B 2 A 1$ has been detected by RT-PCR in 12 out of $30(40.0 \%)$ SLN from breast cancer patients (Nissan et al. 2006).

In addition to the mammary tissue, SCGB2A1 has been found in lachrymal and ocular glands, in prostate and in the pituitary (Lehrer et al. 1998, Sjodin et al. 2005, Xiao et al. 2005, Stoeckelhuber et al. 2006).

\section{SCGB1D2}

Lee et al. (2004) performed a large-scale analysis of mRNA coexpression based on 60 diverse large human datasets containing a total of 62.2 million expression measurements distributed among 3924 micro-arrays. These authors developed a tool (http://benzer.ubic.ca/ tmm/websitedoc.html) allowing the finding of genes that are reliably coexpressed (based on the correlation of their expression profiles) in multiple datasets. Using this tool, it appears that SCGB2A1, SCGB2A2 and SCGB1D2 are frequently coexpressed and that their expression cannot be correlated to that of any other gene, including other secretoglobins. This suggests that expression of the three genes, which are localized on the same gene cluster, is probably regulated by common transcriptional mechanisms.

In accordance, a strong correlation between SCGB2A2 and SCGB1D2 levels has been observed in breast cancer. SCGB1D2 may bind to SCGB2A2 in an antiparallel manner forming a covalent tetrameric complex. The significance of this interaction is not known, however, it appears to be the predominant form of both proteins in breast cancer cells (Colpitts et al. 2001, Carter et al. 2002).
As also observed with SCGB2A2, abundant SCGB1D2 expression has been found in malignant and normal tissues of the breast and in the female genital tract, namely the cervix, uterus and ovary (Zafrakas et al. 2006a).

In summary, the secretoglobins SCGB2A1, SCGB2A2 and SCGB1D2 are expressed at variable levels in subsets of breast tumours. Despite their relatively high breast-specificity, they may also be found in several other tissues, notably glands and steroid-rich organs. Of these secretoglobins, SCGB2A2 has been the most used for DTC detection. Since SCGB2A1, SCGB2A2 and SCGB1D2 are frequently coexpressed, it is likely that, in most cases, DTC that do not express SCGB2A2 will also be negative for SCGB2A1 and SCGB1D2 expressions.

\section{PIP}

Also known as gross cystic disease fluid protein-15, PIP has been used for years to detect breast cancer and follow breast cancer progression and metastasis. It is a small protein that is considered as a highly specific and sensitive marker of apocrine differentiation (Jones et al. 2001). It has been identified in most breast cancer biopsies (Myal et al. 1998, Clark et al. 1999), in correlation with steroid receptor status. In agreement, androgens, oestrogens and glucocorticoids have been found to regulate PIP expression (Murphy et al. 1987).

However, as observed with SCGB2A1, PIP expression level may considerably vary among breast tumours, some of them showing no expression at all. By examining PIP gene expression levels in $11 \mathrm{BCC}$ lines (see above for SCGB2A2), we found elevated PIP mRNA level only in MDA-MB-453 BCC, supporting the global apocrine phenotype of these cells (de Longueville et al. 2005). Therefore, PIP sensitivity in breast cancer may fail.

Despite being highly breast-specific, PIP has also been detected, although generally at low levels, in various other tissues (Mazoujian et al. 1983, Haagensen et al. 1990, Clark et al. 1999, Liu et al. 2004, Tian et al. 2004).

\section{SBEM}

Also known as BS106 (Colpitts et al. 2002). SBEM cDNA was identified based on its preferential representation in libraries prepared from normal breast tissue and breast tumours. SBEM is a small secreted mucin-like protein with strong similarity to many sialomucins (Hubé et al. 2004). In a study of 43 normal human tissues, its presence was largely restricted to the mammary and salivary glands. Regarding cancer tissues, SBEM has 
been detected in breast and prostate (Miksicek et al. 2002). Among breast cancer cell lines, SBEM expression has been found in the ER-positive, well-differentiated, 'luminal epithelial-like' (Lacroix \& Leclercq 2004a, see below 'recent data on breast cancer classification and progression') MCF-7, T-47D and ZR-75-1 BCC, but not in the poorly differentiated, ER-negative, 'basal epithelial-like' MDA-MB-231 cells (Miksicek et al. 2002).

SBEM expression was detected in $>90 \%$ of invasive ductal carcinomas, although with significant differences in expression levels, and correlated with the expression of SCGB2A2. No close correlation was found between SBEM expression and steroid receptor levels or tumour grade (Miksicek et al. 2002).

\section{ESR1}

Although ESR1 has not been used to detect DTC to date, it represents an essential marker of breast cancer. ESR1 is a transcription factor that allows regulatory functions of female sex steroids, mainly $17 \beta$-estradiol, on growth, differentiation and function in several target tissues, including female and male reproductive tract, mammary gland and skeletal and cardiovascular systems. Its key role in the biology and the treatment of breast cancer is well established, as well as the mechanisms underlying its activation and function (for review, see Leclercq et al. 2006). ESR1 is the main mediator of endocrine therapy (tamoxifen, SERMs, aromatase inhibitors), and its detection in tumours and individual cancer cells is thus of considerable clinical importance.

ESR1 is expressed in about two-thirds of all breast cancers. Indeed, ESR 1 is the main discriminator in breast tumour classifications. Its presence is characteristic of a specific class (luminal epithelial-like, see 'recent data on breast cancer classification and progression') of tumours with a well-differentiated, low-grade phenotype. Significant ESR1 expression has also been found in endometroid and ovarian carcinomas.

\section{TFF1 and TFF3}

Both are small cysteine-rich acidic-secreted proteins containing one trefoil domain that has several conserved features, including six cysteine residues with conserved spacing.

Trefoil peptides function as 'luminal epithelium guardians'. They are involved in protection of luminal mucosa and mucosal restitution after damage. Rapid repair of mucous epithelia is essential for preventing inflammation, which is a critical component of cancer progression (Hoffmann 2005).
Abnormal elevated TFF1 and TFF3 levels have been observed in various neoplastic diseases, including breast cancer. TFF3 is widely coexpressed with TFF1 in ER-positive malignant breast cancer cells (Poulsom et al. 1997), and both are upregulated by oestrogens. TFF3 is also induced by growth hormone.

The expression of TFF1 and TFF3 is not found in all breast tumours. Their expression pattern is close to that of ESR1 and the three genes are components of a 'luminal epithelial' signature defining a well-differentiated, low-grade subtype that includes about $65 \%$ of all breast cancers (see 'recent data on breast cancer classification and progression'). Therefore, TFF1 and TFF3 may not be viewed as 'universal' breast tumour markers. In particular, they are unlikely to be informative in the detection of DTC from most aggressive, ER-negative, high-grade tumours.

\section{SPDEF}

It is a member of the 'Ets' family. These transcription factors regulate a number of biological processes, including cell proliferation, differentiation and invasion and are thought to play an important role in oncogenesis. Unlike the majority of Ets factors, SPDEF is expressed exclusively in tissues with a high epithelial content, such as the prostate and the breast (Oettgen et al. 2000, Ghadersohi \& Sood 2001, Mitas et al. 2002). Furthermore, several studies showed SPDEF to be one of the most highly overexpressed mRNAs in human and mouse mammary tumours (Ghadersohi \& Sood 2001, Mitas et al. 2002, Galang et al. 2004).

In breast cancer cells, it has been recently shown that SPDEF could cooperate with ERBB2 to promote motility and invasion. These experimental data suggest that the coevaluation of SPDEF and ERBB2 expressions of DTC could be of high prognostic value (Gunawardane et al. 2005).

\section{ANKRD30A}

ANKRD30A has been previously identified as NY-BR-1 (Nissan et al. 2006) or antigen B726P (Jiang et al. 2002). It was identified based on spontaneous humoural immune responses in breast cancer patients (Jäger et al. 2001, 2002). The protein is regarded as a putative transcription factor, as it contains a bipartite nuclear localization signal motif and a bZIP site (DNA-binding site followed by leucine zipper motif). Additional structural features include five tandem ankyrin repeats, implying a role for ANKRD30A in protein-protein interactions.

In view of its highly restricted expression pattern, ANKRD30A may be considered as a breast 
differentiation antigen that could represent a suitable target for immunotherapy (Jäger et al. 2005, Wang et al. 2006). Indeed, it was found in $80 \%$ of breast cancer specimens, while tumours of other histological types were ANKRD30A-negative. It was also identified in normal breast, normal testis, was inconsistent in prostate, and not found in other tissues (Jäger et al. 2001, 2002). ANKRD30A expression was found in $40-50 \%$ and $60-70 \%$ of primary and metastatic breast cancer specimens respectively (Zehentner et al. 2002b), which has been confirmed by other investigators (O'Brien et al. 2003). More recently, ANKRD30A expression was identified by immunohistochemistry in breast $(60 \%$ of 124 invasive carcinoma lesions), but not in 23 other normal tissues, including prostate and testis, and in breast tumours, but not in lymphoma, seminoma, melanoma, kidney, ovarian, endometrial, prostate and lung cancers (Varga et al. 2006). ANKRD30A has been detected by RT-PCR in 13 out of 30 (43.3\%) SLN from breast cancer patients (Nissan et al. 2006).

Therefore, although being a highly sensitive marker, ANKRD30A is not always expressed by breast cancers. Moreover, its expression has been significantly associated with the differentiation grade. For instance, in a study of 124 invasive breast carcinoma lesions, 20 out of 26 grade 1 (77\%), 24 out of 38 grade $2(63 \%)$, and 30 out of 60 grade $3(50 \%)$ samples were positive. NYBR-1 expression was also significantly associated with LN negativity, presence of ERBB2 amplification and ER expression (Varga et al. 2006). Therefore, ANKRD30A is more likely to be detected in well-differentiated tumours and related DTC.

\section{SERPINB5}

Widely known as maspin, it is an epithelial-specific serine protease inhibitor (serpin) that shares extensive homology to the plasminogen activator inhibitors PAI-1 (SERPINE1) and PAI-2 (SERPINB2).

SERPINB5 expression has been found in the epithelium of several normal organs, including mammary gland (Zhang \& Zhang 2002). In breast tissue, the presence of SERPINB5 seems to be restricted to myoepithelial cells (Maass et al. 2001, Bieche et al. 2003), when compared with the luminal epithelial ones and it has been suggested that those myoepithelial cells form a defensive barrier for the progression from ductal carcinoma in situ to more invasive carcinoma (Sternlicht et al. 1997, Polyak \& Hu 2005). SERPINB5 has also been identified in tumours of various origins, including breast, although in most cases, its level was reduced when compared with normal counterparts (Pemberton et al. 1997, Zhang \& Zhang 2002).
Accumulated evidence shows that SERPINB5 may act as a tumour suppressor. Its extracellular form is sufficient to inhibit tumour cell motility, extracellular matrix degradation and invasion in vitro, and inhibits tumour growth and metastasis in vivo (Zou et al. 1994, Shi et al. 2001). It also inhibits tumour-induced angiogenesis (Zhang et al. 2000). Intracellular SERPINB5 is responsible for an increased cellular sensitivity to apoptosis (Latha et al. 2005, Lockett et al. 2006).

It has been previously suggested that SERPINB5 expression in breast tumours declined with progression and that high SERPINB5 levels were associated to low aggressiveness. For instance, a significant stepwise decrease in maspin expression was shown to occur in the sequence ductal cancer in situ - invasive cancer lymph-node metastasis (Maass et al. 2001).

According to various studies, however, SERPINB5 overexpression has been observed only in a subset (10-35\%) of breast tumours (Maass et al. 2001, Umekita et al. 2002, Kim et al. 2003, Mohsin et al. 2003). In these studies, SERPINB5 levels in breast carcinomas have been directly correlated to tumour size, high grade, high S-phase fraction, aneuploidy, positive p53 status, the presence of comedo-necrosis and of lymphocyte-rich stroma, inversely correlated to the presence of steroid receptors, and identified as a strong indicator of poor prognosis, with shorter relapse-free survival (RFS) and OS (Martin et al. 2000, Umekita et al. 2002, Bieche et al. 2003, Kim et al. 2003, Mohsin et al. 2003, Umekita \& Yoshida 2003). Therefore, despite its tumour suppressor function, SERPINB5 expression seems to be a characteristic of aggressive tumours, supporting its use for DTC detection.

\section{GABRP}

The $\gamma$-aminobutyric acid (GABA) receptor is a multimeric transmembrane chloride ion channel. Sixteen subtypes of GABA-receptor subunits have been categorized within five structural classes $(\alpha 1-6$, $\beta 1-3, \gamma 1-3, \gamma, \varepsilon, \theta, \pi)$. These subunits are thought to assemble in different pentameric complexes (Hedblom \& Kirkness 1997, Zafrakas et al. 2006b).

GABRP was previously identified by in silico analysis of four million ESTs as a candidate gene differentially expressed in breast cancer. It codes for the $\pi$-subunit of the GABA receptor. In a study of 23 normal human tissues, the GABRP expression level was most abundant in the breast. In breast tissue, GABRP is mainly expressed in myoepithelial/basal cells and it is hypothesized that its function could be related to tissue contractility.

GABRP expression was found to be lower in a majority of primary breast tumours when compared 
with corresponding normal tissues. Along the same line, strong GABRP expression was observed in normal epithelial and benign papilloma breast cells, but no signal could be detected in invasive ductal carcinoma, suggesting that GABRP is progressively downregulated with tumour progression, and that it may be useful as a prognostic marker in breast cancer (Zafrakas et al. 2006b). In contrast, in a study of 203 invasive breast cancers, GABRP expression was found high in a subset (16\%) of ER-negative, ERBB2negative, high-grade tumours with basal-like (undifferentiated) phenotype (Symmans et al. 2005). How to explain these discrepancies?

Most in situ breast tumours are of luminal epithelial origin. They express no, or low levels of, SERPINB5 and GABRP, but are located close to the SERPINB5- and GABRP-producing normal intact basal/myoepithelial cell layers. When these tumours progress, they invade and destroy the normal basal/myoepithelial cell layers. Since tumour samples most often include some normal surrounding tissue, we suggest that this might explain why several authors, such as Zafrakas et al. (2006b) have concluded that invasive lesions expressed less SERPINB5 and GABRP than in situ tumours. On the other hand, a minority of breast tumours have a 'basal/myoepitheliallike' phenotype (see below) and likely originate from the transformation of normal SERPINB5- and GABRPexpressing basal/myoepithelial cells. These tumours are most often steroid-receptor negative, ERBB2 negative, have a high grade and are aggressive lesions, supporting the observations of Symmans et al. (2005).

\section{Viability of DTC}

Are most DTC precursors of clinically relevant metastases or just transiently shed cells with limited lifespan?

Clearly, tumour cells are very inefficient in causing metastasis. It has been estimated that only one in 10000 DTC is able to establish metastatic lesions (Liotta \& Stetler-Stevenson 1991). One reason is that the lifespan of many DTC circulating in PB is short. Indeed, the examination of DTC has revealed a high frequency of apoptosis (Mehes et al. 2001, Chambers et al. 2002). It may be speculated that DTC hardly survive their vigorous passage in $\mathrm{PB}$.

The fraction of DTC in PB and BM that express the proliferation marker $\mathrm{Ki}-67$ (absent in the $\mathrm{G}_{0}$ and early- $G_{1}$ phases of the cell cycle) is small and most DTC do not proliferate at the time of primary surgery (Pantel et al. 1993, Braun \& Pantel 1999, Müller et al. 2005). Therefore, many DTC escaping apoptosis are likely in a latent stage (dormant cell-cycle arrest). However, a proportion of DTC isolated from the BM are capable of clonogenic growth in vitro (Ross et al. 1993). Moreover, DTC have been obtained in up to $90 \%$ of breast cancer cases by culturing BM in standard in vitro culture medium, a percentage that was higher than the percentage of DTC directly detected in BM aspirates (Solakoglu et al. 2002, Loo et al. 2005). It is likely that DTC reaching BM are prevented to proliferate by their specific environment. In fact, most DTC appear to remain in the state of dormant cell-cycle arrest for many years; however, their persistence is associated with an unfavourable clinical outcome, suggesting that at least some of these DTC can eventually escape 'dormancy control' and start to expand towards an overt metastasis (Janni et al. 2001, 2005, Wiedswang et al. 2004). Studies in animal models have shown that the last step (resumed proliferation) seems to be particularly rate limiting in the formation of overt metastases (Luzzi et al. 1998). It has been suggested that when reaching BM, DTC are 'immature' and need alterations, possibly subtended by genetic changes to form overt metastases driven by the specific selective pressures of the bone-marrow environment (Gray 2003). At the present time, little is known about what is required for DTC to survive the vigorous passage in blood and the subsequent invasion of organs in patients.

The low proliferative activity or dormancy of individual DTC in BM of patients with non-metastatic cancer at the time of primary surgery (Pantel et al. 1993), might explain the relative resistance of these cells to conventional chemotherapy (Braun et al. 2000a, Naumov et al. 2003). This observation should lead to the development of new therapies that work equally well on proliferating and quiescent cells (e.g. immunotherapy). It must be noted that a series of recent articles discuss the mechanisms underlying cancer cell dormancy (Aguirre-Ghiso 2006, Felsher 2006, Indraccolo et al. 2006, Klein \& Holzel 2006, Marches et al. 2006, Naumov et al. 2006, Ranganathan et al. 2006, Townson \& Chambers 2006, White et al. 2006).

\section{Genetics and phenotype of DTC, when compared with primary tumours}

\section{Recent data on breast cancer classification and progression}

\section{Breast tumour classification}

Recent technological advances have allowed the simultaneous evaluation of multiple RNAs (DNA micro-arrays) or proteins (tissue arrays) in tumour 
samples. These studies have revealed that the breast tumours could be sorted into a very few classes characterized by the high level of expression of specific groups of genes/proteins (signatures, for instance, see Bertucci et al. 2000, Ross \& Perou 2001, Lacroix et al. 2002, 2004, Callagy et al. 2003, Sorlie et al. 2003, Abd El-Rehim et al. 2005, Brenton et al. 2005, Hu et al. 2006). According to these studies, about two-thirds of tumours express features reminiscent of the luminal epithelial component of the breast. These lesions are often well differentiated, have a low grade and demonstrate relatively high levels of steroid receptors, cytokeratins KRT8, KRT18 and KRT19, BCL2, CDH1, MUC1, the transcription factors GATA3, FOXA1, XBP1 (Lacroix \& Leclercq 2004c), TFF1, TFF3, SLC39A6, CDKN1A, CDKN1B and CCND1. In contrast to the 'luminal epithelial-like' lesions, about $15 \%$ of tumours have a low level of the above-cited markers, whereas they express relatively high levels of cytokeratins KRT5 and KRT17, CDH3, EGFR, FOXC1, KIT, SERPINB5, TRIM29, GABRP, MMP7, SLPI and various proliferation markers. Most of these 'basal/myoepithelial-like' tumours are poorly differentiated and have a high grade (Nielsen et al. 2004). Part of them is associated with the rare medullary carcinomas (Bertucci et al. 2006) and mutations in the familial cancer susceptibility BRCAI gene (Foulkes et al. 2003, Lacroix \& Leclercq 2005, 2006). Tumours overexpressing ERBB 2 as a consequence of gene amplification may be grouped into a separate class (ERBB2 subtype), more closely related to the 'basal/myoepithelial-like' than to the 'luminal epithelial-like' lesions. Of interest, the 'luminal epithelial-like', 'basal/myoepithelial-like' and 'ERBB2' classes are also found in breast cancer cell lines (Lacroix \& Leclercq 2004a, Charafe-Jauffret et al. 2006), most of which are derived from DTC (obtained in most cases from pleural effusions).

It must be noted that among the markers listed above, many are more or less associated to a specific class. EGFR, SERPINB5 and GABRP are mostly expressed by 'basal/myoepithelial-like' tumours, while high ERBB2 levels are obviously expressed in lesions of the 'ERBB2' class. ESR1, TFF1 and TFF3, the expression of which is closely correlated, are found at high levels only in 'luminal epithelial-like' tumours. Other markers related to this well-differentiated, low-grade class are the secreted proteins PIP, SCGB2A1, SCGB2A2 and SCGB2D1, as well as the mucins MUC1 and SBEM, the transcription factor SPDEF and ANKRD30A.
Stable portrait of breast cancer during progression, despite increasing genetic complexity

The existence of breast tumour classes defined by gene/protein signatures suggests that any tumour biology reflects to a large extent the biology of the cell of origin at the time of initiation. Tumours originating from more undifferentiated epithelial cells have a rapid growth pattern and more aggressive behaviour and outcome compared with those originating in a more differentiated epithelial cells. Therefore, the 'portrait' of tumours seems to be stable during progression.

We previously compiled and analysed a number of data regarding breast cancer biology, pathology and genetics. We concluded that during progression to metastasis, although undergoing increasing genetic alterations, most breast tumours largely maintain their portrait (luminal epithelial-like, basal/myoepitheliallike, ERBB2). Indeed, the grade (I-III) and the expression of markers, such as ESR1, PGR, TFF1, EGFR, ERBB2, P53 and various proliferation markers, etc. are generally concordant between primaries and metastases (Lacroix et al. 2004). In fact, gene signatures underlying these portraits are preserved throughout the metastatic process of breast cancer (Weigelt et al. 2005). This opposes to the 'classical' view, according to which tumour progression is frequently associated with some degree of dedifferentiation (i.e. loss of ER) and supposes a deep change in the biological status of cancer cells. One consequence is that DTC are expected to express the same markers and, likely, the same properties (for instance, sensitivity or resistance to chemotherapeutic agents) than tumour cells in the corresponding primaries.

While the portrait of tumours appears stable, their progression from in situ to metastasis is accompanied by an increasing genetic complexity. This probably results from the accumulation of various minor (lowfrequency) genetic or epigenetic events at many different sites of the genome, giving rise to a number of different patterns, each restricted to a small cell subpopulation. This genetic micro-heterogeneity has minor effects on the global portrait, but it eventually alter the molecular balances controlling cell adhesion, migratory ability, proteolysis, angiogenesis and, possibly, allow DTC to colonize distant organs and produce secondary tumours (Lacroix et al. 2004).

Although genetic complexity is a hallmark of breast cancer, recent studies have, however, allowed subclassifying tumours into a few categories, based on array-CGH analysis. Among breast tumours, DNA gains in chromosome 1q and loss in 16q appear to be the most frequent alterations. Some ER-positive, low-grade 
tumours have very few copy number alterations in addition to gain of $1 \mathrm{q}$ and loss of $16 \mathrm{q}$ and are associated with the best patient outcome. At the other extreme of genome instability are tumours with many low level copy number aberrations. Copy number losses involving chromosomes 3p, 4, 5q, 11p, 14q, 15q, 17q and 18q are more prevalent in this group composed mainly of ER-negative, high-grade lesions from patients experiencing significantly worse outcome (Loo et al. 2004, Fridlyand et al. 2006). Fridlyand et al. (2006) have identified an additional subgroup comprised of both ER-positive and ER-negative tumours and characterized by the presence of low-level gains and losses and recurrent amplifications. The more frequently seen amplifications in this group, which occurred predominantly in the ER-positive tumours, involved $8 p$, including FGFR1, 11q13, including CCND1 and regions of 20q, including ZNF217.

It is well known that specific gene amplification occurs frequently in breast cancer. For instance, ERBB2, EGFR, MYC, CCND1, MDM2, NCOA3/AIB1, FGFR1, TOP2A, CTTN/EMS1, FGF3, AKT2 and ZNF217 are genes for which amplification has been described in previous breast cancer studies (Albertson et al. 2003, Al-Kuraya et al. 2004). For some of them, their amplification has been linked more or less clearly to the degree of tumour aggressiveness. For instance, ERBB2 and MYC amplifications have been linked to shortened survival, while ERBB2/MYC-coamplified cancers have a worse prognosis than tumours with only one of these amplifications (Al-Kuraya et al. 2004).

Therefore, a decrease of survival is observed with increasing genome instability in primary tumours, but specific DNA gains/losses combinations as well as genes amplifications appear to have more weight in this regard.

\section{Genetic alterations in DTC}

There are indications that DTC may exhibit a considerable genetic diversity, reflecting the instability and micro-heterogeneity observed in primary tumours.

Using a procedure involving whole-genome amplification and subsequent $\mathrm{CGH}$ of single immunostained cells, it has been shown that cytokeratin-positive DTC in the BM of breast cancer patients without clinical signs of overt metastases (stage $\mathrm{M}_{0}$ ) were genetically heterogeneous (Klein et al. 2002). This heterogeneity was reduced with the emergence of clinically evident metastasis (stage $\mathrm{M}_{1}$ ). The fact that DTC in $\mathrm{M}_{1}$ patients closely resemble each other genetically suggests that cells could detach from lesions at secondary sites (e.g. $\mathrm{BM}$ ) and recirculate, and may be cause the appearance of other metastatic sites. As mentioned earlier, it has been hypothesized that BM could serve as a 'reservoir' allowing for DTC to adapt and disseminate later into other organs.

Investigators using a combination of ICC and FISH found that the pattern of genetic aberrations in BM-derived DTC varied considerably among different breast cancer patients (Solakoglu et al. 2002). This is consistent with the CGH-based data of Klein et al. (2002) supporting a plethora of different random changes in $\mathrm{M}_{0}$ cells.

Schmidt-Kittler et al. (2003) also reported a high genetic heterogeneity in $\mathrm{M}_{0}$ cells, although these DTC displayed fewer chromosomal aberrations than primary tumours or cells from $\mathrm{M}_{1}$-stage patients. Numerous $\mathrm{M}_{0}$ DTC without detectable aberration (CGH analysis) were also found by these authors. In $\mathrm{M}_{0}$ cells, genetic aberrations appeared to be randomly generated, while characteristic chromosomal imbalances were observed in $\mathrm{M}_{1}$ cells. This suggests that in breast cancer, tumour cells may disseminate in a far less progressed genomic state than previously thought, and that they acquire aberrations typical of metastatic cells thereafter.

Along the same line, Gangnus et al. (2004) analysed tumour cells in BM of early-stage breast tumour patients for genomic changes by single-cell CGH. The viable disseminated cancer cells had a plethora of copy number changes in their genome. All examined cells showed chromosomal copy number changes with a substantial intercellular heterogeneity and differences to the matching primary tumours.

The further development of $\mathrm{M}_{0}$ cells into metastasis, and hence $\mathrm{M}_{1}$ cells, apparently is a matter of mutation and selection, leading to a plausible explanation for tumour dormancy. In this interpretation, dormancy reflects the time needed for $M_{0}$ cells to acquire the full capacity of unrestrained growth. This selection model is in agreement with the fact that DTC in patients with overt metastases closely resemble each other genetically (Klein et al. 2002).

It must be noted that the genetic changes as observed in DTC from BM (Klein et al. 2002, Solakoglu et al. 2002, Schmidt-Kittler et al. 2003, Gangnus et al. 2004) and PB (Fehm et al. 2002) confirm the tumoural nature of these DTC.

Since specific DNA gains/losses combinations and genes amplifications in primary tumours are associated to prognosis, it would be useful to assess whether such changes are also found in DTC, as well as the possible relationships between their presence in these cells and various parameters (survival of DTC, time before clinical appearance of metastases, metastasis target organs). For instance, the prognostic value of genomic alterations in 
breast DTC has been examined by Austrup et al. (2000). These authors found significant correlations between genomic alterations of the DCC and ERBB2 genes in DTC and relapse-free survival. Furthermore, increasing numbers of genomic imbalances measured in DTC were significantly associated with worse prognosis of recurrent disease.

Some of the genes that are frequently amplified in breast tumours encode proteins that are or could be targeted by specific therapies. For instance, Her-2/neu, the product of ERBB2, is targeted by the antibody trastuzumab, while attempts are made to design molecules preventing the interaction between the ubiquitin ligase MDM2 and the p53 oncogene (Lacroix et al. 2006). At term, the identification of specific gene amplifications in DTC, notably by a combination of array-CGH and FISH could allow to apply specific therapies (Bussey et al. 2006).

\section{Phenotype of DTC}

Individual phenotype comparisons between primary tumours and their corresponding DTC have not been performed as yet, to the best of our knowledge. What is clear, however, is that DTC have been observed in patients independent of the grade, the differentiation status and the ESR1 content of their tumours (for instance, see Gaforio et al. 2003, Cristofanilli et al. 2005a,b, Müller et al. 2005, Benoy et al. 2006). Therefore, the presence of DTC is not restricted to patients with aggressive 'basal/myoepithelial' or 'ERBB2' tumours, which are known to be associated with less favourable outcome. Indeed, DTC seem to distribute along a wide range of phenotypes, as judged by their variable expression of specific markers.

Since the portrait of primary tumours is generally maintained in their corresponding metastases, it can be hypothesized that DTC should also closely resemble the tumour from which they have shed. According to this, DTC from 'luminal epithelial-like' tumours are not expected to express high SERPINB5 or GABRP levels, while markers, such as ESR1, TFF1, TFF3 or the three secretoglobins, should not be found in DTC in patients with a 'basal epithelial-like' primary. As this latter class of tumours is also characterized by lower levels of KRT19, MUC1 and CEACAM5, it is suggested that preanalytical enrichment techniques based on the detection of these markers could occasionally miss the DTC originating from 'basal epithelial-like' lesions. In the near future, the biological characteristics of breast tumours should play a mandatory role in the choice of marker(s) for DTC detection.
DTC are expected to closely resemble their corresponding primaries. However, it has been repeatedly shown that a fraction of ERBB2-negative tumours could be associated with ERBB2-positive DTC (Braun et al. 2001b, Hayes et al. 2002, Zidan et al. 2005, Solomayer et al. 2006). These observations are in line with the fact that a significant percentage of patients with HER2-negative primary tumours develop high concentrations of serum HER2 during tumour progression (Meng et al. 2004a). Although very early ERBB2 amplification in breast tumours has been demonstrated (Schardt et al. 2005), it is possible that this amplification could, in some cases, be acquired relatively late during breast cancer progression, so that the entire primary tumour would be considered as ERBB2 negative, while part of the DTC resulting from this lesion could be ERBB2 positive. Moreover, there could be a specific preselection of ERBB2-positive cells during tumour cell dissemination. The presence of ERBB2-overexpressing cells in a tumour is associated to a higher density of micro-vessels (Sopel et al. 2005), which might favour the haematogenous dissemination of these cells. Moreover, ERBB2-overexpression was found to provide an advantage in in vitro extravasation experiments using disaggregated cells and cell clusters from primary breast cancer tissue (Roetger et al. 1998).

\section{Significance of DTC in LN, PB and BM}

\section{Prognosis and correlations}

Numerous studies have concluded that the presence of DTC in BM, evaluated by ICC or RT-PCR, correlates strongly with an early relapse of breast cancer and decreased patient survival (Landys et al. 1998, Mansi et al. 1999, Braun et al. 2000b, Gebauer et al. 2001, Gerber et al. 2001, Wiedswang et al. 2003, 2004, 2006, Schindlbeck et al. 2004, Weinschenker et al. 2004, Müller \& Pantel 2005, Pantel \& Woelfle 2005, Benoy et al. 2006). As demonstrated by clinical follow-up data on more than 4000 breast cancer patients studied in prospective trials by several international groups, the presence of DTC in BM (identified by ICC at primary diagnosis) predicts the postoperative occurrence of overt metastases in bone and other organs (Braun et al. 2005). Of note, strong correlations between the presence of BM micro-metastases and poor survival have been reported in breast cancer independent from LN metastases (Cote et al. 1991, Braun et al. 2000b, 2001a). That the presence of DTC in the BM of breast cancer patients does not correlate with the outspread of tumour cells into $\mathrm{LN}$ has been reported by other authors (for instance, see Fehm et al. 2004, Benoy et al. 2005, 
Trocciola et al. 2005). For instance, in a study of 68 breast cancer patients, Benoy et al. (2005) showed that the presence or the absence of DTC in LN did not predict the DTC status of BM. Concordance between BM status and LN status was present in only $49 \%$ of all patients.

PB samples are easier to collect than BM samples, yet the prognostic significance of DTC in PB is still uncertain, as it has been less investigated than for DTC in BM. However, a series of recent works indicate that the presence of DTC in PB may be associated with bad prognosis. Using a KRT19-based RT-PCR on 128 patients with stages I and II after removal of the primary breast tumour and before adjuvant chemotherapy, Stathopoulou et al. (2002) found that patients with DTC in PB had a reduced DFS and a significant lower OS. A similar association between the presence of KRT19-positive DTC in PB and reduced DFS was noted in a study of 100 operated patients before the initiation of adjuvant chemotherapy and local radiotherapy (Giatromanolaki et al. 2004). In another series of 100 patients, the presence of CEACAM5-positive DTC in $\mathrm{PB}$ either before or after surgery was also indicative of a reduced DFS; patients who were DTC positive at both times had the worst prognosis (Jotsuka et al. 2004). Using an immunocytometric method, it was found that patients with elevated DTC in PB prior to therapy had worse DFS and OS (Gaforio et al. 2003). Studies involving up to 177 patients with metastatic breast cancer demonstrated that an elevated number of DTC in PB predicted extremely short median DFS and OS, irrespective of the line of treatment, when compared with patients with low or negative DTC (Cristofanilli et al. 2004, 2005a,b, Hayes et al. 2006). More recently, in $167 \mathrm{LN}$-negative patients, the presence of KRT19positive DTC in PB before the initiation of adjuvant chemotherapy was associated with reduced DFS and OS (Xenidis et al. 2006).

Several authors have shown a significant positive correlation between the presence of DTC in PB and BM (as detected by ICC or RT-PCR), although in their studies, only the presence of DTC in BM could be clearly correlated with metastatic relapse or OS (Pierga et al. 2004, Müller et al. 2005, Benoy et al. 2006). For instance, in a recent RT-PCR study using KRT19 and SCGB2A2 as markers, Benoy et al. (2006) found that in contrast to the DTC status in BM, the presence of DTC in the PB had no impact on the OS of the patients. This suggests that the DTC that are able to find their way to the BM and survive there seem to have an increased ability to develop into overt metastases (Pantel \& Brakenhoff 2004). That DTC in BM could be more informative than DTC in PB is notably suggested by a recent study, in which $\mathrm{PB}$ and $\mathrm{BM}$ were prospectively collected from 341 breast cancer patients median 40 months after operation. DTC were present in PB of $10 \%$ of the patients and in BM of 14\%. DTC status in PB and BM were both significantly associated with DFS and breast cancer-specific survival. The presence of DTC in both PB and BM (8 out of 341 patients) resulted in an especially poor prognosis. However, in $\mathrm{LN}$-negative patients, DTC status in BM, but not in $\mathrm{PB}$, predicted differences in DFS (Wiedswang et al. 2006).

It has been suggested that the presence of DTC in PB was an indication of micro-metastasis in BM, but not in LN. For instance, in a study of 47 patients without overt metastasis, all the patients with DTC in PB had micrometastasis in $\mathrm{BM}$, whereas $36 \%$ of patients with micrometastasis in $\mathrm{BM}$ had no circulating cells in $\mathrm{PB}$; there was no correlation between DTC in PB or BM and micro-metastasis in SLN (Zhu et al. 2005). The absence of correlation between DTC in LN and DTC in PB has also been shown by other investigators (see the recent papers of Stathopoulos et al. 2005, Wülfing et al. 2006).

It is important to note that, while many studies, including those that are discussed in the present article, have evaluated the clinical significance of DTC in axillary LN, the significance of micro-metastasis in SLN, especially when detected by highly sensitive techniques, such as mono- or multi-marker RT-PCR (for instance, see Mikhitarian et al. 2005b, Dell'orto et al. 2006, Hughes et al. 2006, Nissan et al. 2006) is still under investigation. To date, even quantitative RT-PCR cannot be regarded as a substitute for an extensive histopathological scrutiny of the SLN in the clinical practice.

In summary, the data currently available from DTC detection in LN, PB and BM suggest that these sites may provide partially non-redundant prognostic information. Whether these information might be complementary remains unclear (Müller and Pantel 2005).

\section{Monitoring the response to therapy - predictive potential of DTC}

An important potential application of DTC detection is the monitoring of therapeutic efficacy in the adjuvant setting. Indeed, the efficacy of adjuvant systemic therapy can be assessed currently only retrospectively in large-scale clinical trials following an observation period of at least 5 years. Consequently, the progress in this form of therapy is slow and is not possible to tailor therapy to an individual patient. The potential of a surrogate marker assay that would permit immediate assessment of therapy-induced effects on DTC is 
therefore evident. It could be possible to identify patients who need additional adjuvant therapy, and even to define this additional therapy, based on the DTC characteristics (e.g. the administration of trastuzumab when DTC overexpress ERBB2) or site of dissemination (e.g. biphosphonate treatment, which might eliminate tumour cells in BM persisting after adjuvant treatment).

Data indicating either the persistence or the disappearance of DTC after systemic treatment have been obtained (Braun et al. 2000a, Smith et al. 2000, Manhani et al. 2001, Xenidis et al. 2003, Bozionellou et al. 2004, Hennessy et al. 2005, Müller et al. 2005, Pachmann et al. 2005, Pantel \& Woelfle 2005, Slade et al. 2005, Stathopoulos et al. 2005, Drageset et al. 2006, Quintela-Fandino et al. 2006). Such discrepancies might reflect differences in the proliferation status of DTC or in the therapeutical agent used.

In the study of Braun et al. (2000a), adjuvant chemotherapy was devoid of effect on the elimination of single dormant tumour cells in BM of high-risk breast cancer patients. Indeed, as most chemotherapeutic agents act by interfering with cell proliferation, they are not expected to eliminate dormant cells. This underlines the need to develop therapeutic agents active on non-proliferating cells. An example of successful immunotherapy is provided by Bozionellou et al. (2004), who were able to remove chemotherapyresistant KRT19-positive DTC in PB and BM of breast cancer patients by administration of the anti-ERBB2 antibody trastuzumab. Pachmann et al. (2005) observed that the response of DTC in PB to chemotherapy was patient-specific. Moreover, this response faithfully reflected the response of the whole tumour to adjuvant therapy. It is well known that tumours may exhibit considerable differences in their response to specific agents. The data of Pachmann et al. (2005) are in agreement with the fact that the global characteristics of BCC, including resistances, do not change during progression from in situ to metastatic tumour (see notably Lacroix et al. 2004). That the DTC number in PB may reflect the outcome of systemic breast cancer treatment was also shown by Smith et al. (2000). Pantel \& Woelfle (2005) concluded that the persistence of DTC in the BM after chemotherapy (paclitaxel-epirubicin) was an independent predictor of reduced OS. Hennessy et al. (2005) observed that in patients receiving primary chemotherapy, those achieving pathologic complete disappearance of DTC in ALN were associated with an excellent prognosis. More recently, a study of 177 patients with metastatic breast cancer has shown that the detection of elevated DTC numbers in PB at any time during therapy was an accurate indication of subsequent rapid disease progression and mortality (Hayes et al. 2006). In these patients, a change in therapy would be needed. In the study of Quintela-Fandino et al. (2006), PB micro-metastases presence after adjuvant chemotherapy was found to predict both relapse and death more powerful than classical factors (oestrogen receptor and progesterone receptor status, tumour size, age, tumour grade, number of nodes affected) in high-risk breast cancer patients undergoing high-dose chemotherapy. Micro-metastases search using a five-gene panel appeared to be a more accurate procedure than classical approaches involving only one or two genes.

Regarding adjuvant chemotherapy, it has been suggested that it could have profound and long-lasting negative effects on the BM immune system (SoloMayer et al. 2003). Since an increased incidence of DTC has been observed in patients with immune dysfunction (Campbell et al. 2005), it is possible that in some cases, chemotherapy could contribute to both eradicate DTC and favour their persistence in BM.

Large prospective clinical studies are now required to evaluate whether eradication of DTC in PB and BM after systemic therapy translates into a longer DFS and OS.

\section{A new concept: breast cancer stem cells}

In recent years, studies using animal models have suggested that only a small proportion of breast tumour cells, the so-called 'breast cancer stem cells' (BCSC), have the capacity for extensive proliferation and regrowth of the tumour. Indeed, these cells, which comprise between 1 and $10 \%$ of the total cell population, display the defining stem-cell properties of self-renewal and differentiation. Self-renewal drives tumourigenesis, whereas differentiation contributes to tumour phenotypic heterogeneity.

Based on these observations, the stem-cell model of carcinogenesis proposes that breast cancers originate in tissue stem or progenitor cells probably through deregulation of self-renewal pathways (including the Wnt, Notch and Hedgehog pathways, see Liu et al. 2005). This leads to expansion of this cell population which then may undergo further genetic or epigenetic changes to become fully transformed (for a recent review on tumour stem cells, see Wicha et al. 2006). Although the concept of cancer stem cells is very appealing, it must be mentioned that there remain many uncertainties, both theoretical and technical, about the interpretation of the results (see notably Hill 2006). 
Regarding the dissemination process, it is possible that although either BCSC or their more differentiated progeny may be capable of forming micro-metastases, only BCSC have the self-renewal capacity to create clinically relevant macroscopic metastases. Moreover, by analogy with normal stem cells, BCSC might remain dormant at metastatic sites until they are activated by the appropriate signals from the micro-environment. Therefore, the most interesting breast DTC could well be the BCSC. This implies that techniques aiming to identify disseminated breast cancer cells through their expression of differentiation markers will be unable to recognize the most 'dangerous' tumour cells. BCSC seem to express CD44 and ESA/TACSTD1 (Al-Hajj et al. 2003). However, as pointed out by Hill (2006), these markers are not obviously related to stemness, but rather are features of a differentiating phenotype. Additional BCSC-specific markers remain to be defined. Recently, Glinsky et al. (2005) developed an 11-gene (ANK3, BUB1, CCNB1, CES2, FGFR2, GBX2, HCFC1, KNTC2, MKI67, RNF2, USP22) signature whose expression was regulated by the stem-cell self-renewal polycomb gene BMI1 (Liu et al. 2006). Remarkably, expression of this 'stem-cell gene' signature was associated with a poor prognosis for ten different types of human malignancies, including breast cancer (Glinsky et al. 2005). Future works should examine potential correlations between the expression of this 'death signature' by disseminated breast tumour cells and the development of clinically detectable metastases.

As discussed earlier, DTC escaping apoptosis are likely in a latent stage (dormant cell-cycle arrest). This concept of tumour cell dormancy may directly relate to stem-cell biology. Stem cells usually exist in a quiescent $\mathrm{G}_{0}$ state and self-renew only when they receive appropriate signals from their niche environment.

\section{Conclusion}

The age-adjusted death rate for cancer (all types) has not significantly declined over the last 50 years (Leaf 2004). Moreover, the incidence of many cancers, including breast cancer, is increasing. At the present time, the probability for a woman to develop breast cancer in Western countries is higher than 0.13 (Jemal et al. 2005). In Europe, about 130000 women die from breast cancer each year. In most cases, death results from the dissemination of cancer cells and their proliferation at secondary sites, underlining the importance of controlling and preventing these events.
Recent technical advances have allowed the detection of single or small groups of breast cancer cells disseminated in LN, PB and BM, thus making visible these intermediates between primary tumours and metastases. This has notably made clear that two distinct routes may lead to tumour cell dissemination. Some cells may transit by $\mathrm{LN}$ before accessing the PB and BM (lymphogenous route), while other DTC appear able to directly enter the blood stream (haematogenous route). The mechanism leading to direct haematogenous tumour cell dissemination is not clearly established as yet, but it is likely favoured by a high micro-vessel density (MVD) in the primary lesion, as this latter feature has been correlated to the presence of DTC in PB or BM (Fox et al. 1997, Gerber et al. 2001, Giatromanolaki et al. 2004, Benoy et al. 2005). Antiangiogenic therapies are, therefore, expected to decrease the number of DTC in patients. Of interest, tumours overexpressing ERBB2 seem to be associated with higher MVD (Sopel et al. 2005), suggesting that cells from these tumours and ERBB2positive cells incidentally emerging in an ERBB2negative tumour could have a specific advantage for dissemination, at least via the haematogenous route.

The ability to detect DTC with high sensitivity and specificity, when compared with classical serum tumour markers, opens interesting clinical perspectives. Potential applications include:

Screening of women at risk for breast cancer.

Since tumour cells may in some cases disseminate very early in the natural history of breast cancer, one can envisage the detection of DTC in women apparently without cancer, but who are regularly screened because they are considered at high risk.

Estimating prognosis after tumour resection.

Evaluating the need for a therapy. At the present time, the selection of patients is based on their statistical risk of developing tumour recurrence, without knowing whether they actually harbour any DTC. This uncertainty may lead to overtreatment of patients with cancer with toxic agents that exert severe side effects. For example, only $20-25 \%$ of LN-negative breast cancer patients undergo metastatic relapse within 10 years postsurgery, but more than $90 \%$ of these patients are supposed to receive chemotherapy according to recommendations (Goldhirsch et al. 2003). DTC detection in PB or $\mathrm{BM}$ may represent an additional clinical marker to identify those LN-negative patients who are cured by surgery alone and need no additional adjuvant systemic therapy. 
Monitoring the efficacy of a therapy. This might contribute to predict which patients with early stage or metastatic disease will recur. This may also possibly support the shift to another treatment.

Monitoring for recurrence after apparently successful adjuvant therapy in patients with early stage or metastatic disease.

Destroying DTC before they develop into metastases.

One can speculate that the observed moderate rate of response in advanced cancer patients might be caused by the fact that solid metastases form physiological barriers that prevent the access of macromolecules such as antibodies from the circulation in the metastatic lesion (Jain 1990). From this point of view, DTC are expected to be more easily accessible for intravenously applied immunoglobulins.

Contrasting with $\mathrm{LN}$, which are often removed at surgery, PB and BM might theoretically allow repeated detection of DTC in patients. However, as BM aspiration is rather uncomfortable, PB seems to be the most suitable DTC source. One might consider consecutive evaluations of DTC in PB as a succession of regular and easily practicable real-time biopsies, which could not only be included in the future in the normal follow up of breast cancer patients, but also in the design of clinical trials using biological therapies directed against specific targets.

Before introduction of DTC detection into clinical use, much job remains to be done. To clearly establish the prognostic and predictive value of DTC, a major requirement is the standardization of detection systems and the obtainment of an agreement on threshold values. Another crucial step is the definition of optimal multimarker assays, as no single ideal marker exists for DTC detection. The choice of markers should be based on various considerations. The biology of the primary tumour is important, as different breast cancer subtypes, associated to different gene expression patterns, have been identified. This may explain why most markers used, to date, are found at variable levels among DTC. For several of these markers, such as the secretoglobins (SCGB2A1, SCGB2A2, SCGB1D2), the amplitude of variation in gene expression level may be enormous, from the absence of expression in some tumour cells to very high mRNA levels in other DTC. In some cases, marker overexpression may be the consequence of gene amplification. Since amplification events are characteristic of tumour cells, these markers, such as ERBB2, have a high potential interest. Another important criterion for marker choice is the possibility to use the selected marker as a target for therapy. ESR1 (for endocrine therapy), MUC1, ERBB2, ANKRD30A (for immunotherapy), are examples of such markers. In the future, a big challenge will be the identification and the establishment of clinical usefulness of additional immunotherapy targets, such as NY-ESO-1 (Sugita et al. 2004, Jäger and Knuth 2005), as standard cytotoxic chemotherapy is inefficient in non-proliferating DTC.

\section{Acknowledgements}

There is no conflict of interest that would prejudice the impartiality of this article. The author was partly supported by 'Fondation Fornarina' and 'SciMedWeb' . This article is dedicated to the memory of Albert Lacroix (1935-2006). Merci pour toujours, Papa!

\section{References}

Abd El-Rehim DM, Ball G, Pinder SE, Rakha E, Paish C, Robertson JF, Macmillan D, Blamey RW \& Ellis IO 2005 High-throughput protein expression analysis using tissue microarray technology of a large well-characterized series identifies biologically distinct classes of breast cancer confirming recent cDNA expression analysis. International Journal of Cancer 116 340-350.

Abdul-Rasool S, Kidson SH, Panieri E, Dent D, Pillay K \& Hanekom GS 2006 An evaluation of molecular markers for improved detection of breast cancer metastases in sentinel nodes. Journal of Clinical Pathology 59 289-297.

Aguirre-Ghiso JA 2006 The problem of cancer dormancy: understanding the basic mechanisms and identifying therapeutic opportunities. Cell Cycle 5 1740-1743.

Aihara T, Fujiwara Y, Ooka M, Sakita I, Tamaki Y \& Monden M 1999 Mammaglobin B as a novel marker for detection of breast cancer micrometastases in axillary lymph nodes by reverse transcription-polymerase chain reaction. Breast Cancer Research and Treatment 58 137-140.

Albertson DG, Collins C, McCormick F \& Gray JW 2003 Chromosome aberrations in solid tumors. Nature Genetics 34 369-376.

Al-Hajj M, Wicha MS, Benito-Hernandez A, Morrison SJ \& Clarke MF 2003 Prospective identification of tumorigenic breast cancer cells. PNAS 100 3983-3988.

Alix-Panabières C, Brouillet JP, Fabbro M, Yssel H, Rousset T, Maudelonde T, Choquet-Kastylevsky G \& Vendrell JP 2005 Characterization and enumeration of cells secreting tumor markers in the peripheral blood of breast cancer patients. Journal of Immunological Methods 299 177-188.

Al-Kuraya K, Schraml P, Torhorst J, Tapia C, Zaharieva B, Novotny H, Spichtin H, Maurer R, Mirlacher M, Kochli O et al. 2004 Prognostic relevance of gene amplifications and coamplifications in breast cancer. Cancer Research $648534-8540$. 
Austrup F, Uciechowski P, Eder C, Bockmann B, Suchy B, Driesel G, Jackel S, Kusiak I, Grill HJ \& Giesing M 2000 Prognostic value of genomic alterations in minimal residual cancer cells purified from the blood of breast cancer patients. British Journal of Cancer 83 1664-1673.

Backus J, Laughlin T, Wang Y, Belly R, White R, Baden J, Min CJ, Mannie A, Tafra L, Atkins D et al. 2005 Identification and characterization of optimal gene expression markers for detection of breast cancer metastasis. Journal of Molecular Diagnosis 7 327-336.

Baker MK, Mikhitarian K, Osta W, Callahan K, Hoda R, Brescia F, Kneuper-Hall R, Mitas M, Cole DJ \& Gillanders WE 2003 Molecular detection of breast cancer cells in the peripheral blood of advanced-stage breast cancer patients using multimarker real-time reverse transcription-polymerase chain reaction and a novel porous barrier density gradient centrifugation technology. Clinical Cancer Research 9 4865-4871.

Becker RM, Darrow C, Zimonjic DB, Popescu NC, Watson MA \& Fleming TP 1998 Identification of mammaglobin B, a novel member of the uteroglobin gene family. Genomics $\mathbf{5 4}$ 70-78.

Ben Hsieh H, Marrinucci D, Bethel K, Curry DN, Humphrey M, Krivacic RT, Kroener J, Kroener L, Ladanyi A, Lazarus N et al. 2006 High speed detection of circulating tumor cells. Biosensors and Bioelectronics 21 1893-1899.

Benoy IH, Salgado R, Elst H, Van Dam P, Weyler J, Van Marck E, Scharpe S, Vermeulen PB \& Dirix LY 2005 Relative microvessel area of the primary tumour, and not lymph node status, predicts the presence of bone marrow micrometastases detected by reverse transcriptase polymerase chain reaction in patients with clinically nonmetastatic breast cancer. Breast Cancer Research 7 R210-R219.

Benoy IH, Elst H, Philips M, Wuyts H, Van Dam P, Scharpe S, Van Marck E, Vermeulen PB \& Dirix LY 2006 Real-time RT-PCR detection of disseminated tumour cells in bone marrow has superior prognostic significance in comparison with circulating tumour cells in patients with breast cancer. British Journal of Cancer 94 672-680.

Berois N, Varangot M, Aizen B, Estrugo R, Zarantonelli L, Fernandez P, Krygier G, Simonet F, Barrios E, Muse I et al. 2000 Molecular detection of cancer cells in bone marrow and peripheral blood of patients with operable breast cancer. Comparison of CK19, MUC1 and CEA using RT-PCR. European Journal of Cancer 36 717-723.

Bertucci F, Houlgatte R, Benziane A, Granjeaud S, Adelaide J, Tagett R, Loriod B, Jacquemier J, Viens P, Jordan B et al. 2000 Gene expression profiling of primary breast carcinomas using arrays of candidate genes. Human Molecular Genetics 9 2981-2999.

Bertucci F, Finetti P, Cervera N, Charafe-Jauffret E, Mamessier E, Adelaïde J, Debono S, Houvenaeghel G, Maraninchi D, Viens P et al. 2006 Gene expression profiling shows medullary breast cancer is a subgroup of basal breast cancer. Cancer Research 66 4636-4644.
Bieche I, Girault I, Sabourin JC, Tozlu S, Driouch K, Vidaud M \& Lidereau R 2003 Prognostic value of maspin mRNA expression in ER alpha-positive postmenopausal breast carcinomas. British Journal of Cancer 88 863-870.

Bleiweiss IJ, Nagi CS \& Jaffer S 2006 Axillary sentinel lymph nodes can be falsely positive due to iatrogenic displacement and transport of benign epithelial cells in patients with breast carcinoma. Journal of Clinical Oncology 24 2013-2018.

Bosma AJ, Weigelt B, Lambrechts AC, Verhagen OJ, Pruntel R, Hart AA, Rodenhuis S \& van't Veer LJ 2002 Detection of circulating breast tumor cells by differential expression of marker genes. Clinical Cancer Research 8 1871-1877.

Bostick PJ, Chatterjee S, Chi DD, Huynh KT, Giuliano AE, Cote R \& Hoon DS 1998 Limitations of specific reverse transcriptase polymerase chain reaction markers in the detection of metastases in the lymph nodes and blood of breast cancer patients. Journal of Clinical Oncology 16 2632-2640.

Bozionellou V, Mavroudis D, Perraki M, Papadopoulos S, Apostolaki S, Stathopoulos E, Stathopoulou A, Lianidou E \& Georgoulias V 2004 Trastuzumab administration can effectively target chemotherapy-resistant cytokeratin-19 messenger RNA-positive tumor cells in the peripheral blood of patients with breast cancer. Clinical Cancer Research $\mathbf{1 0}$ 8185-8194.

Braun S \& Pantel K 1999 Biological characteristics of micrometastatic cancer cells in bone marrow. Cancer and Metastasis Reviews 18 75-90.

Braun S \& Naume B 2005 Circulating and disseminated tumor cells. Journal of Clinical Oncology 23 1623-1626.

Braun S, Kentenich C, Janni W, Hepp F, de Waal J, Willgeroth F, Sommer H \& Pantel K $2000 a$ Lack of effect of adjuvant chemotherapy on the elimination of single dormant tumor cells in bone marrow of high-risk breast cancer patients. Journal of Clinical Oncology 18 80-86.

Braun S, Pantel K, Muller P, Janni W, Hepp F, Kentenich CR, Gastroph S, Wischnik A, Dimpfl T, Kindermann G et al. $2000 b$ Cytokeratin-positive cells in the bone marrow and survival of patients with stage I, II, or III breast cancer. New England Journal of Medicine 342 525-533.

Braun S, Cevatli BS, Assemi C, Janni W, Kentenich CR, Schindlbeck C, Rjosk D \& Hepp F 2001a Comparative analysis of micrometastasis to the bone marrow and lymph nodes of node-negative breast cancer patients receiving no adjuvant therapy. Journal of Clinical Oncology 19 1468-1475.

Braun S, Cevatli BS, Assemi C, Janni W, Kentenich CR, Schindlbeck C, Rjosk D \& Hepp F $2001 b$ ErbB2 overexpression on occult metastatic cells in bone marrow predicts poor clinical outcome of stage I-III breast cancer patients. Cancer Research 61 1890-1895.

Braun S, Vogl FD, Naume B, Janni W, Osborne MP, Coombes RC, Schlimok G, Diel IJ, Gerber B, Gebauer G 
et al. 2005 A pooled analysis of bone marrow micrometastasis in breast cancer. New England Journal of Medicine 353 793-802.

Brenton JD, Carey LA, Ahmed AA \& Caldas C 2005 Molecular classification and molecular forecasting of breast cancer: ready for clinical application? Journal of Clinical Oncology 23 7350-7360.

Brown NM, Stenzel TT, Friedman PN, Henslee J, Huper G \& Marks JR 2006 Evaluation of expression based markers for the detection of breast cancer cells. Breast Cancer Research and Treatment 97 41-47.

Bussey KJ, Chin K, Lababidi S, Reimers M, Reinhold WC, Kuo WL, Gwadry F, Ajay W, Kouros-Mehr H, Fridlyand J et al. 2006 Integrating data on DNA copy number with gene expression levels and drug sensitivities in the NCI-60 cell line panel. Molecular Cancer Therapeutics 5 853-867.

Callagy G, Cattaneo E, Daigo Y, Happerfield L, Bobrow LG, Pharoah PD \& Caldas C 2003 Molecular classification of breast carcinomas using tissue microarrays. Diagnostic Molecular Pathology 12 27-34.

Campbell MJ, Scott J, Maecker HT, Park JW \& Esserman LJ 2005 Immune dysfunction and micrometastases in women with breast cancer. Breast Cancer Research and Treatment 91 163-171.

Carter D, Douglass JF, Cornellison CD, Retter MW, Johnson JC, Bennington AA, Fleming TP, Reed SG, Houghton RL, Diamond DL et al. 2002 Purification and characterization of the mammaglobin/lipophilin B complex, a promising diagnostic marker for breast cancer. Biochemistry $\mathbf{4 1}$ 6714-6722.

Chambers AF, Groom AC \& MacDonald IC 2002 Dissemination and growth of cancer cells in metastatic sites. Nature Reviews Cancer 2 563-572.

Charafe-Jauffret E, Ginestier C, Monville F, Finetti P, Adélaïde J, Cervera N, Xerri L, Jacquemier J, Birnbaum D \& Bertucci F 2006 Gene expression profiling of breast cell lines identifies potential new basal markers. Oncogene 25 2273-2284.

Ciborowski P \& Finn OJ 2002 Non-glycosylated tandem repeats of MUC1 facilitate attachment of breast tumor cells to normal human lung tissue and immobilized extracellular matrix proteins (ECM) in vitro: potential role in metastasis. Clinical and Experimental Metastasis 19 339-345.

Clark JW, Snell L, Shiu RP, Orr FW, Maitre N, Vary CP, Cole DJ \& Watson PH 1999 The potential role for prolactin-inducible protein (PIP) as a marker of human breast cancer micrometastasis. British Journal of Cancer 81 1002-1008.

Colpitts TL, Billing-Medel P, Friedman P, Granados EN, Hayden M, Hodges S, Menhart N, Roberts L, Russell J \& Stroupe SD 2001 Mammaglobin is found in breast tissue as a complex with BU101. Biochemistry 40 11048-11059.

Colpitts TL, Billing P, Granados E, Hayden M, Hodges S, Roberts L, Russell J, Friedman P \& Stroupe S 2002
Identification and immunohistochemical characterization of a mucin-like glycoprotein expressed in early stage breast carcinoma. Tumor Biology 23 263-278.

Corradini P, Voena C, Astolfi M, Delloro S, Pilotti S, Arrigoni G, Bregni M, Pileri A \& Gianni AM 2001 Maspin and mammaglobin genes are specific markers for RT-PCR detection of minimal residual disease in patients with breast cancer. Annals of Oncology 12 1693-1698.

Cote RJ, Rosen PP, Lesser ML, Old LJ \& Osborne MP 1991 Prediction of early relapse in patients with operable breast cancer by detection of occult bone micrometastases. Journal of Clinical Oncology 9 1749-1756.

Cote RJ, Peterson HF, Chaiwun B, Gelber RD, Goldhirsch A, Castiglione-Gertsch M, Gusterson B \& Neville AM 1999 Role of immunohistochemical detection of lymph-node metastases in management of breast cancer. International Breast Cancer Study Group. Lancet 354 896-900.

Cristofanilli M, Budd GT, Ellis MJ, Stopeck A, Matera J, Miller MC, Reuben JM, Doyle GV, Allard WJ, Terstappen LW et al. 2004 Circulating tumor cells, disease progression, and survival in metastatic breast cancer. New England Journal of Medicine 351 781-791.

Cristofanilli M, Hayes DF, Budd GT, Ellis MJ, Stopeck A, Reuben JM, Doyle GV, Matera J, Allard WJ, Miller MC et al. 2005 a Circulating tumor cells: a novel prognostic factor for newly diagnosed metastatic breast cancer. Journal of Clinical Oncology 23 1420-1430.

Cristofanilli M, Budd GT, Ellis MJ, Stopeck A, Matera J, Miller MC, Doyle GV, Allard WJ, Terstappen LW \& Hayes DF $2005 b$ Presence of circulating tumor cells (CTC) in metastatic breast cancer (MBC) predicts rapid progression and poor prognosis. Journal of Clinical Oncology 23 Supplement 524.

de Graaf H, Maelandsmo GM, Ruud P, Forus A, Oyjord T, Fodstad O \& Hovig E 1997 Ectopic expression of target genes may represent an inherent limitation of RT-PCR assays used for micrometastasis detection: studies on the epithelial glycoprotein gene EGP-2. International Journal of Cancer 72 191-196.

Dell'orto P, Olivia Biasi M, Del Curto B, Zurrida S, Galimberti V \& Viale G 2006 Assessing the status of axillary sentinel lymph nodes of breast carcinoma patients by a real-time quantitative RT-PCR assay for mammaglobin $1 \mathrm{mRNA}$. Breast Cancer Research and Treatment 98 185-190.

de Longueville F, Lacroix M, Barbuto AM, Bertholet V, Gallo D, Larsimont D, Marcq L, Zammatteo N, Boffe S, Leclercq $\mathrm{G}$ et al. 2005 Molecular characterization of breast cancer cell lines by a low-density microarray. International Journal of Oncology 27 881-892.

De Luca A, Pignata S, Casamassimi A, D’Antonio A, Gridelli C, Rossi A, Cremona F, Parisi V, De Matteis A \& Normanno N 2000 Detection of circulating tumor cells in carcinoma patients by a novel epidermal growth factor receptor reverse transcription-PCR assay. Clinical Cancer Research 6 1439-1444. 
Drageset V, Nesland JM, Erikstein B, Skovlund E, Sommer H, Anker G, Wist E, Lundgren S, Bergh J \& Kvalheim G 2006 Monitoring of disseminated tumor cells in bone marrow in high-risk breast cancer patients treated with high-dose chemotherapy. International Journal of Cancer 118 2877-2881.

Eltahir EM, Mallinson DS, Birnie GD, Hagan C, George WD \& Purushotham AD 1998 Putative markers for the detection of breast carcinoma cells in blood. British Journal of Cancer 77 1203-1207.

Emens LA, Reilly RT \& Jaffee EM 2005 Breast cancer vaccines: maximizing cancer treatment by tapping into host immunity. Endocrine-Related Cancer 12 $1-17$.

Fabisiewicz A, Kulik J, Kober P, Brewczynska E, Pienkowski T \& Siedlecki JA 2004 Detection of circulating breast cancer cells in peripheral blood by a two-marker reverse transcriptase-polymerase chain reaction assay. Acta Biochimica Polonica 51 747-755.

Fehm T, Sagalowsky A, Clifford E, Beitsch P, Saboorian H, Euhus D, Meng S, Morrison L, Tucker T, Lane N et al. 2002 Cytogenetic evidence that circulating epithelial cells in patients with carcinoma are malignant. Clinical Cancer Research 8 2073-2084.

Fehm T, Becker S, Pergola-Becker G, Kramer B, Gruber I, Sotlar K, Kurek R, Wallwiener D \& Solomayer E 2004 Influence of tumor biological factors on tumor cell dissemination in primary breast cancer. Anticancer Research 24 4211-4216.

Felsher DW 2006 Tumor dormancy: death and resurrection of cancer as seen through transgenic mouse models. Cell Cycle 5 1808-1811.

Ferrucci PF, Rabascio C, Mazzetta C, Cocorocchio E, Agazzi A, Vanazzi A, Cinieri S, Peccatori FA, Paolucci M, Bertolini F et al. 2004 Mammaglobin expression in leukapheresis products is a predictive marker of poor prognosis in women with high-risk breast cancer. Clinical Cancer Research $\mathbf{1 0}$ 6039-6046.

Fetsch PA, Cowan KH, Weng DE, Freifield A, Filie AC \& Abati A 2000 Detection of circulating tumor cells and micrometastases in stage II, III and IV breast cancer patients utilizing cytology and immunohistochemistry. Diagnostic Cytopatholgy 22 323-328.

Fiegl H, Millinger S, Müller-Holzner E, Marth C, Ensinger C, Berger A, Klocker H, Goebel G \& Widschwendter M 2005 Circulating tumor-specific DNA: a marker for monitoring efficacy of adjuvant therapy in cancer patients. Cancer Research 65 1141-1145.

Fisher B, Jeong JH, Anderson S, Bryant J, Fisher ER \& Wolmark N 2002 Twenty-five year follow-up of a randomized trial comparing radical mastectomy, total mastectomy, and total mastectomy followed by irradiation. New England Journal of Medicine 347 $567-575$.
Foulkes WD, Stefansson IM, Chappuis PO, Begin LR, Goffin JR, Wong N, Trudel M \& Akslen LA 2003 Germline BRCA1 mutations and a basal epithelial phenotype in breast cancer. Journal of the National Cancer Institute 95 1482-1485.

Fox SB, Leek RD, Bliss J, Mansi JL, Gusterson B, Gatter KC \& Harris AL 1997 Association of tumor angiogenesis with bone marrow micrometastases in breast cancer patients. Journal of the National Cancer Institute 89 1044-1049.

Freire T, Berois N, Sonora C, Varangot M, Barrios E \& Osinaga E 2006 UDP- $N$-acetyl-D-galactosamine:polypeptide $N$-acetylgalactosaminyltransferase 6 (ppGalNAcT6) mRNA as a potential new marker for detection of bone marrow-disseminated breast cancer cells. International Journal of Cancer 119 1383-1388.

Fridlyand J, Snijders AM, Ylstra B, Li H, Olshen A, Segraves R, Dairkee S, Tokuyasu T, Ljung BM, Jain AN et al. 2006 Breast tumor copy number aberration phenotypes and genomic instability. BMC Cancer 696.

Gaforio JJ, Serrano MJ, Sanchez-Rovira P, Sirvent A, DelgadoRodriguez M, Campos M, de la Torre N, Algarra I, Duenas R \& Lozano A 2003 Detection of breast cancer cells in the peripheral blood is positively correlated with estrogenreceptor status and predicts for poor prognosis. International Journal of Cancer 107 984-990.

Galang CK, Muller WJ, Foos G, Oshima RG \& Hauser CA 2004 Changes in the expression of many Ets family transcription factors and of potential target genes in normal mammary tissue and tumors. Journal of Biological Chemistry 279 11281-11292.

Gangnus R, Langer S, Breit E, Pantel K \& Speicher MR 2004 Genomic profiling of viable and proliferative micrometastatic cells from early-stage breast cancer patients. Clinical Cancer Research 10 3457-3464.

Gebauer G, Fehm T, Merkle E, Beck EP, Lang N \& Jager W 2001 Epithelial cells in bone marrow of breast cancer patients at time of primary surgery: clinical outcome during long-term follow-up. Journal of Clinical Oncology 19 3669-3674.

Gerber B, Krause A, Muller H, Richter D, Reimer T, Makovitzky J, Herrnring C, Jeschke U, Kundt G \& Friese K 2001 Simultaneous immunohistochemical detection of tumor cells in lymph nodes and bone marrow aspirates in breast cancer and its correlation with other prognostic factors. Journal of Clinical Oncology 19 960-971.

Ghadersohi A \& Sood AK 2001 Prostate epithelium-derived Ets transcription factor mRNA is overexpressed in human breast tumors and is a candidate breast tumor marker and a breast tumor antigen. Clinical Cancer Research 7 2731-2738.

Giatromanolaki A, Koukourakis MI, Kakolyris S, Mavroudis D, Kouroussis C, Mavroudi C, Perraki M, Sivridis E \& Georgoulias V 2004 Assessment of highly angiogenic and disseminated in the peripheral blood disease in breast cancer patients predicts for resistance to adjuvant chemotherapy and early relapse. International Journal of Cancer 108 620-627. 
Gilbey AM, Burnett D, Coleman RE \& Holen I 2004 The detection of circulating breast cancer cells. Journal of Clinical Pathology 57 903-911.

Gillanders WE, Mikhitarian K, Hebert R, Mauldin PD, Palesch Y, Walters C, Urist MM, Mann GB, Doherty G, Herrmann VM et al. 2004 Molecular detection of micrometastatic breast cancer in histopathology-negative axillary lymph nodes correlates with traditional predictors of prognosis. Annals of Surgery 239 828-837.

Glinsky GV, Berezovska O \& Glinskii AB 2005 Microarray analysis identifies a death-from-cancer signature predicting therapy failure in patients with multiple types of cancer. Journal of Clinical Investigation 115 1503-1521.

Goeminne JC, Guillaume T, Salmon M, Machiels JP, D'Hondt V \& Symann M 1999 Unreliability of carcinoembryonic antigen (CEA) reverse transcriptasepolymerase chain reaction (RT-PCR) in detecting contaminating breast cancer cells in peripheral blood stem cells due to induction of CEA by growth factors. Bone Marrow Transplantation 24 769-775.

Goldhirsch A, Wood WC, Gelber RD, Coates AS, Thurlimann B \& Senn HJ 2003 Meeting highlights: updated international expert consensus on the primary therapy of early breast cancer. Journal of Clinical Oncology 21 3357-3365.

Gradilone A, Gazzaniga P, Silvestri I, Gandini O, Trasatti L, Lauro S, Frati L \& Agliano AM 2003 Detection of CK19, CK20 and EGFR mRNAs in peripheral blood of carcinoma patients: correlation with clinical stage of disease. Oncology Reports 10 217-222.

Gray JW 2003 Evidence emerges for early metastasis and parallel evolution of primary and metastatic tumors. Cancer Cell 4 4-6.

Grunewald K, Haun M, Urbanek M, Fiegl M, Muller-Holzner E, Gunsilius E, Dunser M, Marth C \& Gastl G 2000

Mammaglobin gene expression: a superior marker of breast cancer cells in peripheral blood in comparison to epidermalgrowth-factor receptor and cytokeratin-19. Laboratory Investigations 80 1071-1077.

Guan XF, Hamedani MK, Adeyinka A, Walker C, Kemp A, Murphy LC, Watson PH \& Leygue E 2003 Relationship between mammaglobin expression and estrogen receptor status in breast tumors. Endocrine 21 245-250.

Gunawardane RN, Sgroi DC, Wrobel CN, Koh E, Daley GQ \& Brugge JS 2005 Novel role for PDEF in epithelial cell migration and invasion. Cancer Research 65 11572-11580.

Haagensen DE Jr Dilley WG, Mazoujian G \& Wells SA Jr 1990 Review of GCDFP-15. An apocrine marker protein. Annals of the New York Academy of Sciences 586 161-173.

Hager G, Cacsire-Castillo Tong D, Schiebel I, Rezniczek GA, Watrowski R, Speiser P \& Zeillinger R 2005 The use of a panel of monoclonal antibodies to enrich circulating breast cancer cells facilitates their detection. Gynecological Oncology 98 211-216.
Han JH, Kang Y, Shin HC, Kim HS, Kang YM, Kim YB \& Oh SY 2003 Mammaglobin expression in lymph nodes is an important marker of metastatic breast carcinoma. Archives of Pathology and Laboratory Medicine 127 1330-1334.

Harigopal M, Berger AJ, Camp RL, Rimm DL \& Kluger HM 2005 Automated quantitative analysis of E-cadherin expression in lymph node metastases is predictive of survival in invasive ductal breast cancer. Clinical Cancer Research 11 4083-4089.

Hawes D, Neville AM \& Cote RJ 2001 Detection of occult metastasis in patients with breast cancer. Seminars in Surgery and Oncology 20 312-318.

Hayes DF, Walker TM, Singh B, Vitetta ES, Uhr JW, Gross S, Rao C, Doyle GV \& Terstappen LW 2002 Monitoring expression of HER-2 on circulating epithelial cells in patients with advanced breast cancer. International Journal of Oncology 21 1111-1117.

Hayes DF, Cristofanilli M, Budd GT, Ellis MJ, Stopeck A, Miller MC, Matera J, Allard WJ, Doyle GV \& Terstappen LWWM 2006 Circulating tumor cells at each follow-up time point during therapy of metastatic breast cancer patients predict progression-free and overall survival. Clinical Cancer Research 12 4218-4224.

Hedblom E \& Kirkness EF 1997 A novel class of GABAA receptor subunit in tissue of the reproductive system. Journal of Biological Chemistry 272 15346-15350.

Hennessy BT, Hortobagyi GN, Rouzier R, Kuerer H, Sneige N, Buzdar AU, Kau SW, Fornage B, Sahin A, Broglio K et al. 2005 Outcome after pathologic complete eradication of cytologically proven breast cancer axillary node metastases following primary chemotherapy. Journal of Clinical Oncology 23 9304-9311.

Hill RP 2006 Identifying cancer stem cells in solid tumors: case not proven. Cancer Research 66 1891-1895.

Hoffmann W 2005 Trefoil factors TFF (trefoil factor family) peptide-triggered signals promoting mucosal restitution. Cellular and Molecular Life Sciences 62 2932-2938.

Houghton RL, Dillon DC, Molesh DA, Zehentner BK, Xu J, Jiang J, Schmidt C, Frudakis A, Repasky E, Maltez Filho A et al. 2001 Transcriptional complementarity in breast cancer: application to detection of circulating tumor cells. Molecular Diagnosis 6 79-91.

Hu XC \& Chow LWC 2001 Detection of circulating breast cancer cells with multiple marker RT-PCR assay. Anticancer Research 21 421-424.

Hu XC, Loo WT \& Chow LW 2003 Surgery related shedding of breast cancer cells as determined by RT-PCR assay. Journal of Surgical Oncology 82 228-232.

Hu Z, Fan C, Oh DS, Marron JS, He X, Qaqish BF, Livasy C, Carey LA, Reynolds E, Dressler L et al. 2006 The molecular portraits of breast tumors are conserved across microarray platforms. BMC Genomics 796.

Hubé F, Mutawe M, Leygue E \& Myal Y 2004 Human small breast epithelium mucin: the promise of a new breast tumor biomarker. DNA and Cell Biology 23 842-849. 
Hughes SJ, Xi L, Raja S, Gooding W, Cole DJ, Gillanders WE, Mikhitarian K, McCarty K, Silver S, Ching J et al. 2006 A rapid, fully automated, molecular-based assay accurately analyzes sentinel lymph nodes for the presence of metastatic breast cancer. Annals of Surgery 243 389-398.

Indraccolo S, Favaro E \& Amadori A 2006 Dormant tumors awaken by a short-term angiogenic burst: the spike hypothesis. Cell Cycle 5 1751-1755.

International (Ludwig) Breast Cancer Study Group 1990 Prognostic importance of occult axillary lymph node micrometastases from breast cancers. Lancet 335 1565-1568.

Jäger D \& Knuth A 2005 Antibodies and vaccines - hope or illusion. The Breast 14 631-635.

Jäger D, Stockert E, Gure AO, Scanlan MJ, Karbach J, Jager E, Knuth A, Old LJ \& Chen YT 2001 Identification of a tissuespecific putative transcription factor in breast tissue by serological screening of a breast cancer library. Cancer Research 61 2055-2061.

Jäger D, Unkelbach M, Frei C, Bert F, Scanlan MJ, Jäger E, Old LJ, Chen YT \& Knuth A 2002 Identification of tumorrestricted antigens NY-BR-1, SCP-1, and a new cancer/testis-like antigen NW-BR-3 by serological screening of a testicular library with breast cancer serum. Cancer Immunity 25.

Jäger D, Karbach J, Pauligk C, Seil I, Frei C, Chen YT, Old LJ, Knuth A \& Jäger E 2005 Humoral and cellular immune responses against the breast cancer antigen NY-BR-1: definition of two HLA-A2 restricted peptide epitopes. Cancer Immunity 511.

Jain RK 1990 Physiological barriers to delivery of monoclonal antibodies and other macromolecules in tumors. Cancer Research 50 814s-819s.

Janku F, Kleibl Z, Novotny J, Tesarova P, Petruzelka L \& Matous B 2004 Mammaglobin A, a novel marker of minimal residual disease in early stages breast cancer. Neoplasma 51 204-208.

Janni W, Hepp F, Rjosk D, Kentenich C, Strobl B, Schindlbeck C, Hantschmann P, Sommer H, Pantel K \& Braun S 2001 The fate and prognostic value of occult metastatic cells in the bone marrow of patients with breast carcinoma between primary treatment and recurrence. Cancer 92 46-53.

Janni W, Rack B, Schindlbeck C, Strobl B, Rjosk D, Braun S, Sommer H, Pantel K, Gerber B \& Friese K 2005 The persistence of isolated tumor cells in bone marrow from patients with breast carcinoma predicts an increased risk for recurrence. Cancer 103 884-891.

Jaramillo A, Narayanan K, Campbell LG, Benshoff ND, Lybarger L, Hansen TH, Fleming TP, Dietz JR \& Mohanakumar T 2004 Recognition of HLA-A2-restricted mammaglobin-A-derived epitopes by CD8 + cytotoxic T lymphocytes from breast cancer patients. Breast Cancer Research and Treatment 88 29-41.
Jemal A, Murray T, Ward E, Samuels A, Tiwari RC, Ghafoor A, Feuer EJ \& Thun MJ 2005 Cancer statistics. CA: A Cancer Journal for Clinicians 55 10-30.

Jiang Y, Harlocker SL, Molesh DA, Dillon DC, Stolk JA, Houghton RL, Repasky EA, Badaro R, Reed SG \& Xu J 2002 Discovery of differentially expressed genes in human breast cancer using subtracted cDNA libraries and cDNA microarrays. Oncogene 21 2270-2282.

Jones C, Damiani S, Wells D, Chaggar R, Lakhani SR \& Eusebi V 2001 Molecular cytogenetic comparison of apocrine hyperplasia and apocrine carcinoma of the breast. American Journal of Pathology 158 207-214.

Jotsuka T, Okumura Y, Nakano S, Nitta H, Sato T, Miyachi M, Suzumura K \& Yamashita J 2004 Persistent evidence of circulating tumor cells detected by means of RT-PCR for CEA mRNA predicts early relapse: a prospective study in node-negative breast cancer. Surgery 135 419-426.

Jung R, Petersen K, Kruger W, Wolf M, Wagener C, Zander A \& Neumaier M 1999 Detection of micrometastasis by cytokeratin 20 RT-PCR is limited due to stable background transcription in granulocytes. British Journal of Cancer $\mathbf{8 1}$ 870-873.

Kim DH, Yoon DS, Dooley WC, Nam ES, Ryu JW, Jung KC, Park HR, Sohn JH, Shin HS \& Park YE 2003 Association of maspin expression with the high histological grade and lymphocyte-rich stroma in early-stage breast cancer. Histopathology 42 37-42.

Klein CA \& Holzel D 2006 Systemic cancer progression and tumor dormancy: mathematical models meet single cell genomics. Cell Cycle 5 1788-1798.

Klein CA, Schmidt-Kittler O, Schardt JA, Pantel K, Speicher MR \& Riethmuller G 1999 Comparative genomic hybridization, loss of heterozygosity, and DNA sequence analysis of single cells. PNAS 96 4494-4499.

Klein CA, Blankenstein TJ, Schmidt-Kittler O, Petronio M, Polzer B, Stoecklein NH \& Riethmuller G 2002 Genetic heterogeneity of single disseminated tumor cells in minimal residual cancer. Lancet 360 683-689.

Klug J, Beier HM, Bernard A, Chilton BS, Fleming TP, Lehrer RI, Miele L, Pattabiraman N \& Singh G 2000 Uteroglobin/Clara cell 10-kDa family of proteins: nomenclature committee report. Annals of the New York Academy of Sciences 923 348-354.

Kwon S, Kang SH, Ro J, Jeon CH, Park JW \& Lee ES 2005 The melanoma antigen gene as a surveillance marker for the detection of circulating tumor cells in patients with breast carcinoma. Cancer 104 251-256.

Lacroix M \& Leclercq G 2004a Relevance of breast cancer cell lines as models for breast tumours: an update. Breast Cancer Research and Treatment 83 249-289.

Lacroix M \& Leclercq G 2004b An updated view on cell lines as in vitro models for breast tumors. In Focus on Breast Cancer Research, pp 131-182. Ed P Andrew. Yao. New York: Nova Science Publishers. 
Lacroix M \& Leclercq G 2004c About GATA3, HNF3A, and $\mathrm{XBP} 1$, three genes co-expressed with the oestrogen receptor-alpha gene (ESR1) in breast cancer. Molecular and Cellular Endocrinology 219 1-7.

Lacroix M \& Leclercq G 2005 The 'portrait' of hereditary breast cancer. Breast Cancer Research and Treatment 89 297-304.

Lacroix M \& Leclercq G 2006 Hereditary breast cancer: an update on genotype and phenotype. In New Breast Cancer Research, pp 27-51. Ed P Andrew. Yao. New York: Nova Science Publishers.

Lacroix M, Zammatteo N, Remacle J \& Leclercq G 2002 A low-density DNA microarray for analysis of markers in breast cancer. International Journal of Biological Markers 17 5-23.

Lacroix M, Toillon RA \& Leclercq G 2004 Stable 'portrait' of breast tumors during progression: data from biology, pathology and genetics. Endocrine-Related Cancer 11 497-522.

Lacroix M, Toillon RA \& Leclercq G 2006 P53 and breast cancer: an update. Endocrine-Related Cancer 13 293-325.

Landys K, Persson S, Kovarik J, Hultborn R \& Holmberg E 1998 Prognostic value of bone marrow biopsy in operable breast cancer patients at the time of initial diagnosis: results of a 20-year median follow-up. Breast Cancer Research and Treatment 49 27-33.

Latha K, Zhang W, Cella N, Shi HY \& Zhang M 2005 Maspin mediates increased tumor cell apoptosis upon induction of the mitochondrial permeability transition. Molecular and Cellular Biology 25 1737-1748.

Leaf C 2004 Why we're losing the war on cancer and how to win it. Avastin, Erbitux, Gleevec. The new wonder drugs might make you think we're finally beating this dreaded scourge. We're not. Here's how to turn the fight around. Fortune 149 76-97.

Leclercq G, Lacroix M, Laïos I \& Laurent G 2006 Estrogen receptor alpha: impact of ligands on intracellular shuttling and turnover rate in breast cancer cells. Current Cancer Drug Targets 6 39-64.

Lee HK, Hsu AK, Sajdak J, Qin J \& Pavlidis P 2004 Coexpression analysis of human genes across many microarray data sets. Genome Research 14 1085-1094.

Lehrer RI, Xu G, Abduragimov A, Dinh NN, Qu XD, Martin D \& Glasgow BJ 1998 Lipophilin, a novel heterodimeric protein of human tears. FEBS Letters 432 163-167.

Leitzel K, Lieu B, Curley E, Smith J, Chinchilli V, Rychlik W \& Lipton A 1998 Detection of cancer cells in peripheral blood of breast cancer patients using reverse transcriptionpolymerase chain reaction for epidermal growth factor receptor. Clinical Cancer Research 4 3037-3043.

Leone F, Perissinotto E, Viale A, Cavalloni G, Taraglio S, Capaldi A, Piacibello W, Torchio B \& Aglietta M 2001 Detection of breast cancer cell contamination in leukopheresis product by real-time quantitative polymerase chain reaction. Bone Marrow Transplantation 27 517-523.
Ligtenberg MJ, Buijs F, Vos HL \& Hilkens J 1992 Suppression of cell aggregation by high levels of episialin. Cancer Research 52 2318-2324.

Liotta LA \& Stetler-Stevenson WG 1991 Tumor invasion and metastasis: an imbalance of positive and negative regulation. Cancer Research 51 5054s-5059s.

Liu Z, Kim J, Sypek JP, Wang IM, Horton H, Oppenheim FG \& Bochner BS 2004 Gene expression profiles in human nasal polyp tissues studied by means of DNA microarray. Journal of Allergy and Clinical Immunology 114 783-790.

Liu S, Dontu G \& Wicha MS 2005 Mammary stem cells, selfrenewal pathways, and carcinogenesis. Breast Cancer Research 7 86-95.

Liu S, Dontu G, Mantle ID, Patel S, Ahn NS, Jackson KW, Suri P \& Wicha MS 2006 Hedgehog signaling and Bmi-1 regulate self-renewal of normal and malignant human mammary stem cells. Cancer Research 66 6063-6071.

Lockett J, Yin S, Li X, Meng Y \& Sheng S 2006 Tumor suppressive maspin and epithelial homeostasis. Journal of Cellular Biochemistry 97 651-660.

Loo LW, Grove DI, Williams EM, Neal CL, Cousens LA, Schubert EL, Holcomb IN, Massa HF, Glogovac J, Li CI et al. 2004 Array comparative genomic hybridization analysis of genomic alterations in breast cancer subtypes. Cancer Research 64 8541-8549.

Loo WTY, Fong JHM, Zhu L, Cheung MNB \& Chow LWC 2005 The value of bone marrow aspirates culture for the detection of bone marrow micrometastasis in breast cancer. Biomedicine and Pharmacotherapy 59 S384-S386.

Lopez-Guerrero JA, Gilabert PB, Gonzalez EB, Sanz Alonso MA, Perez JP, Talens AS, Oraval EA, de la Rubia Comos J \& Boix SB 1999 Use of reverse-transcriptase polymerase chain reaction (RT-PCR) for carcinoembryonic antigen, cytokeratin 19, and maspin in the detection of tumor cells in leukopheresis products from patients with breast cancer: comparison with immunocytochemistry. Journal of Hematotherapy 8 53-61.

Luppi M, Morselli M, Bandieri E, Federico M, Marasca R, Barozzi P, Ferrari MG, Savarino M, Frassoldati A \& Torelli G 1998 Sensitive detection of circulating breast cancer cells by reverse-transcriptase polymerase chain reaction of maspin gene. Annals of Oncology 7 619-624.

Luzzi KJ, MacDonald IC, Schmidt EE, Kerkvliet N, Morris VL, Chambers AF \& Groom AC 1998 Multistep nature of metastatic inefficiency: dormancy of solitary cells after successful extravasation and limited survival of early micrometastases. American Journal of Pathology 153 865-873.

Maass N, Teffner M, Rosel F, Pawaresch R, Jonat W, Nagasaki K \& Rudolph P 2001 Decline in the expression of the serine proteinase inhibitor maspin is associated with tumour progression in ductal carcinomas of the breast. Journal of Pathology 195 321-326.

Manhani AR, Manhani R, Soares HP, Bendit I, Lopes F, Nicoletti AG, Fonseca FL, Novaes M, Zatta SM, Arias V 
et al. 2001 CK-19 expression by RT-PCR in the peripheral blood of breast cancer patients correlates with response to chemotherapy. Breast Cancer Research and Treatment 66 249-254.

Manna PP, Jaramillo A, Majumder K, Campbell LG, Fleming TP, Dietz JR, Dipersio JF \& Mohanakumar T 2003 Generation of CD8 + cytotoxic T lymphocytes against breast cancer cells by stimulation with mammaglobin-Apulsed dendritic cells. Breast Cancer Research and Treatment 79 133-136.

Mansi JL, Gogas H, Bliss JM, Gazet JC, Berger U \& Coombes RC 1999 Outcome of primary breast cancer patients with micrometastases: a long-term follow-up study. Lancet 354 197-202.

Marches R, Scheuermann R \& Uhr J 2006 Cancer dormancy: from mice to man. Cell Cycle 5 1772-1778.

Martin KJ, Kritzman BM, Price LM, Koh B, Kwan CP, Zhang X, Mackay A, O'Hare MJ, Kaelin CM, Mutter GL et al. 2000 Linking gene expression patterns to therapeutic groups in breast cancer. Cancer Research 60 2232-2238.

Masuda TA, Kataoka A, Ohno S, Murakami S, Mimori K, Utsunomiya T, Inoue H, Tsutsui H, Kinoshita J, Masuda N et al. 2005 Detection of occult cancer cells in peripheral blood and bone marrow by quantitative RT-PCR assay for cytokeratin-7 in breast cancer patients. International Journal of Oncology 26 721-730.

Mazoujian G, Pinkus GS, Davis S \& Haagensen DE Jr 1983 Immunohistochemistry of a gross cystic disease fluid protein (GCDFP-15) of the breast. A marker of apocrine epithelium and breast carcinomas with apocrine features. American Journal of Pathology 110 105-112.

Mehes G, Witt A, Kubista E \& Ambros PF 2001 Circulating breast cancer cells are frequently apoptotic. American Journal of Pathology 159 17-20.

Meng S, Tripathy D, Shete S, Ashfaq R, Haley B, Perkins S, Beitsch P, Khan A, Euhus D, Osborne C et al. $2004 a$ HER-2 gene amplification can be acquired as breast cancer progresses. PNAS 101 9393-9398.

Mercatali L, Valenti V, Calistri D, Calpona S, Rosti G, Folli S, Gaudio M, Frassineti GL, Amadori D \& Flamini E 2006 RT-PCR determination of maspin and mammaglobin B in peripheral blood of healthy donors and breast cancer patients. Annals of Oncology 17 424-428.

Mikhitarian K, Gillanders WE, Almeida JS, Martin RH, Varela JC, Metcalf JS, Cole DJ \& Mitas M $2005 a$ An innovative microarray strategy identifies informative molecular markers for the detection of micrometastatic breast cancer. Clinical Cancer Research 11 3697-3704.

Mikhitarian K, Martin RH, Mitas M, Mauldin PD, Palesch Y, Metcalf JS, Cole DJ \& Gillanders WE 2005b Mims Study Group Molecular analysis improves sensitivity of breast sentinel lymph node biopsy: results of a multi-institutional prospective cohort study. Surgery 138 474-481.
Miksicek RJ, Myal Y, Watson PH, Walker C, Murphy LC \& Leygue E 2002 Identification of a novel breast- and salivary gland-specific, mucin-like gene strongly expressed in normal and tumor human mammary epithelium. Cancer Research 62 2736-2740.

Min CJ, Tafra L \& Verbanac KM 1998 Identification of superior markers for polymerase chain reaction detection of breast cancer metastases in sentinel lymph nodes. Cancer Research 58 4581-4584.

Mitas M, Mikhitarian K, Walters C, Baron PL, Elliott BM, Brothers TE, Robison JG, Metcalf JS, Palesch YY, Zhang Z et al. 2001 Quantitative real-time RT-PCR detection of breast cancer micrometastasis using a multigene marker panel. International Journal of Cancer 93 162-171.

Mitas M, Mikhitarian K, Hoover L, Lockett MA, Kelley L, Hill A, Gillanders WE \& Cole DJ 2002 Prostate-Specific Ets (PSE) factor: a novel marker for detection of metastatic breast cancer in axillary lymph nodes. British Journal of Cancer 86 899-904.

Mohsin SK, Zhang M, Clark GM \& Craig Allred D 2003 Maspin expression in invasive breast cancer: association with other prognostic factors. Journal of Pathology 199 432-435.

Müller V \& Pantel K 2005 BM micrometastases and circulating tumor cells in breast cancer patients: where have we been, where are we now and where does the future lie? Cytotherapy 7 478-482.

Müller HM, Widschwendter A, Fiegl H, Ivarsson L, Goebel G, Perkmann E, Marth C \& Widschwendter M 2003 DNA methylation in serum of breast cancer patients: an independent prognostic marker. Cancer Research 63 7641-7645.

Müller V, Stahmann N, Riethdorf S, Rau T, Zabel T, Goetz A, Janicke F \& Pantel K 2005 Circulating tumor cells in breast cancer: correlation to bone marrow micrometastases, heterogeneous response to systemic therapy and low proliferative activity. Clinical Cancer Research $\mathbf{1 1}$ 3678-3685.

Murphy LC, Lee-Wing M, Goldenberg GJ \& Shiu RP 1987 Expression of the gene encoding a prolactin-inducible protein by human breast cancers in vivo: correlation with steroid receptor status. Cancer Research 47 4160-4164.

Myal Y, Iwasiow B, Cosby H, Yarmill A, Blanchard A, Tsuyuki D, Fresnoza A, Duckworth ML \& Shiu RPC 1998 Analysis of tissue- and hormone-specific regulation of the human prolactin-inducible proteidgross cystic disease fluid protein-1 5 gene in transgenic mice. Journal of Molecular Endocrinology 21 217-223.

Narayanan K, Jaramillo A, Benshoff ND, Campbell LG, Fleming TP, Dietz JR \& Mohanakumar T 2004 Response of established human breast tumors to vaccination with mammaglobin-A cDNA. Journal of the National Cancer Institute 96 1388-1396.

Naumov GN, Townson JL, MacDonald IC, Wilson SM, Bramwell VH, Groom AC \& Chambers AF 2003 
Ineffectiveness of doxorubicin treatment on solitary dormant mammary carcinoma cells or late-developing metastases. Breast Cancer Research and Treatment $\mathbf{8 2}$ 199-206.

Naumov GN, Akslen LA \& Folkman J 2006 Role of angiogenesis in human tumor dormancy: animal models of the angiogenic switch. Cell Cycle 5 1779-1787.

Nielsen TO, Hsu FD, Jensen K, Cheang M, Karaca G, Hu Z, Hernandez-Boussard T, Livasy C, Cowan D, Dressler L et al. 2004 Immunohistochemical and clinical characterization of the basal-like subtype of invasive breast carcinoma. Clinical Cancer Research 10 5367-5374.

Nissan A, Jager D, Roystacher M, Prus D, Peretz T, Eisenberg I, Freund HR, Scanlan M, Ritter G, Old LJ et al. 2006 Multimarker RT-PCR assay for the detection of minimal residual disease in sentinel lymph nodes of breast cancer patients. British Journal of Cancer 94 681-685.

Núñez-Villar MJ, Martinez-Arribas F, Pollan M, Lucas AR, Sanchez J, Tejerina A \& Schneider J 2003 Elevated mammaglobin (h-MAM) expression in breast cancer is associated with clinical and biological features defining a less aggressive tumour phenotype. Breast Cancer Research 5 R65-R70.

O'Brien N, Maguire TM, O’Donovan N, Lynch N, Hill AD, McDermott E, O’Higgins N \& Duffy MJ 2002 Mammaglobin a: a promising marker for breast cancer. Clinical Chemistry 48 1362-1364.

O'Brien N, O'Donovan N, Hill AD, McDermott E, O'Higgins N \& Duffy MJ 2003 B726P, a gene expressed specifically in breast tissue. Proceedings of the American Association of Cancer Research 3263.

O'Brien N, O'Donovan N, Ryan B, Hill AD, McDermott E, O’Higgins N \& Duffy MJ 2005 Mammaglobin A in breast cancer: existence of multiple molecular forms. International Journal of Cancer 114 623-627.

Oettgen P, Finger E, Sun Z, Akbarali Y, Thamrongsak U, Boltax J, Grall F, Dube A, Weiss A, Brown L et al. 2000 PDEF, a novel prostate epithelium-specific ets transcription factor, interacts with the androgen receptor and activates prostate-specific antigen gene expression. Journal of Biological Chemistry 275 1216-1225.

Ouellette RJ, Richard D \& Maicas E 2004 RT-PCR for mammaglobin genes, MGB1 and MGB2, identifies breast cancer micrometastasis in sentinel lymph nodes. American Journal of Clinical Pathology 121 637-643.

Pachmann K, Camara O, Kavallaris A, Schneider U, Schünemann S \& Höffken K 2005 Quantification of the response of circulating epithelial cells to neoadjuvant treatment for breast cancer: a new tool for therapy monitoring. Breast Cancer Research 7 R975-R979.

Pantel K \& Brakenhoff RH 2004 Dissecting the metastatic cascade. Nature Reviews Cancer 4 448-456.
Pantel K \& Woelfle U 2005 Detection and molecular characterisation of disseminated tumour cells: implications for anti-cancer therapy. Biochimica et Biophysica Acta 1756 53-64.

Pantel K, Schlimok G, Braun S, Kutter D, Lindemann F, Schaller G, Funke I, Izbicki JR \& Riethmuller G 1993 Differential expression of proliferation-associated molecules in individual micrometastatic carcinoma cells. Journal of the National Cancer Institute 85 1419-1424.

Pantel K, Cote RJ \& Fodstad O 1999 Detection and clinical importance of micrometastatic disease. Journal of the National Cancer Institute 91 1113-1124.

Pemberton PA, Tipton AR, Pavloff N, Smith J, Erickson JR, Mouchabeck ZM \& Kiefer MC 1997 Maspin is an intracellular serpin that partitions into secretory vesicles and is present at the cell surface. Journal of Histochemistry and Cytochemistry 45 1697-1706.

Pierga JY, Bonneton C, Vincent-Salomon A, de Cremoux P, Nos C, Blin N, Pouillart P, Thiery JP \& Magdelénat H 2004 Clinical significance of immunocytochemical detection of tumor cells using digital microscopy in peripheral blood and bone marrow of breast cancer patients. Clinical Cancer Research 10 1392-1400.

Pierga JY, Bonneton C, Magdelenat H, Vincent-Salomon A, Nos C, Boudou E, Pouillart P, Thiery JP \& de Cremoux P 2005 Real-time quantitative PCR determination of urokinase-type plasminogen activator receptor (UPAR) expression of isolated micrometastatic cells from bone marrow of breast cancer patients. International Journal of Cancer 114 291-298.

Polyak K \& Hu M 2005 Do myoepithelial cells hold the key for breast tumor progression? Journal of Mammary Gland Biology and Neoplasia 10 231-247.

Poulsom R, Hanby AM, Lalani EN, Hauser F, Hoffmann W \& Stamp GW 1997 Intestinal trefoil factor (TFF 3) and pS2 (TFF 1), but not spasmolytic polypeptide (TFF 2) mRNAs are co-expressed in normal, hyperplastic, and neoplastic human breast epithelium. Journal of Pathology 183 30-38.

Quintela-Fandino M, Lopez JM, Hitt R, Gamarra S, Jimeno A, Ayala R, Hornedo J, Guzman C, Gilsanz F \& Cortes-Funes H 2006 Breast cancer-specific mRNA transcripts presence in peripheral blood after adjuvant chemotherapy predicts poor survival among high-risk breast cancer patients treated with high-dose chemotherapy with peripheral blood stem cell support. Journal of Clinical Oncology 24 3611-3618.

Rakha EA, Boyce RW, Abd El-Rehim D, Kurien T, Green AR, Paish EC, Robertson JF \& Ellis IO 2005 Expression of mucins (MUC1, MUC2, MUC3, MUC4, MUC5AC and MUC6) and their prognostic significance in human breast cancer. Modern Pathology 18 1295-1304.

Ranganathan AC, Adam AP \& Aguirre-Ghiso JA 2006 Opposing roles of mitogenic and stress signaling pathways in the induction of cancer dormancy. Cell Cycle 5 1799-1807. 
Reinholz MM, Nibbe A, Jonart LM, Kitzmann K, Suman VJ, Ingle JN, Houghton R, Zehentner B, Roche PC \& Lingle WL 2005 Evaluation of a panel of tumor markers for molecular detection of circulating cancer cells in women with suspected breast cancer. Clinical Cancer Research 11 3722-3732.

Ring A, Smith IE \& Dowsett M 2004 Circulating tumour cells in breast cancer. Lancet Oncology 5 79-88.

Ring AE, Zabaglo L, Ormerod MG, Smith IE \& Dowsett M 2005 Detection of circulating epithelial cells in the blood of patients with breast cancer: comparison of three techniques. British Journal of Cancer 92 906-912.

Roetger A, Merschjann A, Dittmar T, Jackisch C, Barnekow A \& Brandt B 1998 Selection of potentially metastatic subpopulations expressing c-erbB-2 from breast cancer tissue by use of an extravasation model. American Journal of Pathology 153 1797-1806.

Roncella S, Ferro P, Bacigalupo B, Dessanti P, Giannico A, Gorji N, Moroni M, Tozzini S, Pensa F, Gianquinto D et al. 2006 Relationship between human mammaglobin mRNA expression in breast cancer tissue and clinicopathologic features of the tumors. Journal of Experimental and Clinical Cancer Research 25 65-72.

Ross DT \& Perou CM 2001 A comparison of gene expression signatures from breast tumors and breast tissue derived cell lines. Disease Markers 17 99-109.

Ross AA, Cooper BW, Lazarus HM, Mackay W, Moss TJ, Ciobanu N, Tallman MS, Kennedy MJ, Davidson NE, Sweet D et al. 1993 Detection and viability of tumor cells in peripheral blood stem cell collections from breast cancer patients using immunocytochemical and clonogenic assay techniques. Blood 82 2605-2610.

Ruud P, Fodstad O \& Hovig E 1999 Identification of a novel cytokeratin 19 pseudogene that may interfere with reverse transcriptase-polymerase chain reaction assays used to detect micrometastatic tumor cells. International Journal of Cancer 80 119-125.

Savtchenko ES, Schiff TA, Jiang CK, Freedberg IM \& Blumenberg M 1988 Embryonic expression of the human 40$\mathrm{kD}$ keratin: evidence from a processed pseudogene sequence. American Journal of Human Genetics 43 630-637.

Schardt JA, Meyer M, Hartmann CH, Schubert F, SchmidtKittler O, Fuhrmann C, Polzer B, Petronio M, Eils R \& Klein CA 2005 Genomic analysis of single cytokeratinpositive cells from bone marrow reveals early mutational events in breast cancer. Cancer Cell 8 227-239.

Schindlbeck C, Janni W, Shabani N, Rack B, Gerber B, Schmitt M, Harbeck N, Sommer H, Braun S \& Friese K 2004 Comparative analysis between the HER2 status in primary breast cancer tissue and the detection of isolated tumor cells in the bone marrow. Breast Cancer Research and Treatment 87 65-74.

Schindlbeck C, Jeschke U, Schulze S, Karsten U, Janni W, Rack B, Sommer H \& Friese K 2005 Characterization of disseminated tumor cells in the bone marrow of breast cancer patients by the Thomsen-Friedenreich tumor antigen. Histochemistry and Cell Biology 123 631-637.

Schmidt-Kittler O, Ragg T, Daskalakis A, Granzow M, Ahr A, Blankenstein TJ, Kaufmann M, Diebold J, Arnholdt H, Muller P et al. 2003 From latent disseminated cells to overt metastasis: genetic analysis of systemic breast cancer progression. PNAS 100 7737-7742.

Shi HY, Zhang W, Liang R, Abraham S, Kittrell FS, Medina D \& Zhang M 2001 Blocking tumor growth, invasion, and metastasis by maspin in a syngeneic breast cancer model. Cancer Research 61 6945-6951.

Sidransky D 1997 Nucleic acid-based methods for the detection of cancer. Science 278 1054-1059.

Silva AL, Diamond J, Silva MR \& Passas-Coelho JL 2001a Cytokeratin 20 is not a reliable molecular marker for occult breast cancer cell detection in haematological tissues. Breast Cancer Research and Treatment 66 59-66.

Silva JM, Dominguez G, Silva J, Garcia JM, Sanchez A, Rodriguez O, Provencio M, Espana P \& Bonilla F $2001 b$ Detection of epithelial messenger RNA in the plasma of breast cancer patients is associated with poor prognosis tumor characteristics. Clinical Cancer Research 7 2821-2825.

Silva JM, Garcia JM, Dominguez G, Silva J, Miralles C, Cantos B, Coca S, Provencio M, Espana P \& Bonilla F 2002 Persistence of tumor DNA in plasma of breast cancer patients after mastectomy. Annals of Surgical Oncology 9 71-76.

Silva HA, Abraul E, Raimundo D, Dias MF, Marques C, Guerra C, de Oliveira CF \& Regateiro FJ 2006 Molecular detection of EGFRvIII-positive cells in the peripheral blood of breast cancer patients. European Journal of Cancer 42 2617-2622.

Siwek B, Larsimont D, Lacroix M \& Body JJ 1998 Establishment and characterization of three new breast-cancer cell lines. International Journal of Cancer 76 677-683.

Sjodin A, Guo D, Lund-Johansen M, Krossnes BK, Lilleng P, Henriksson R \& Hedman H 2005 Secretoglobins in the human pituitary: high expression of lipophilin B and its down-regulation in pituitary adenomas. Acta Neuropathologica 109 381-386.

Slade MJ, Singh A, Smith BM, Tripuraneni G, Hall E, Peckitt C, Fox S, Graham H, Luchtenborg M, Sinnett HD et al. 2005 Persistence of bone marrow micrometastases in patients receiving adjuvant therapy for breast cancer: results at 4 years. International Journal of Cancer 114 94-100.

Smerage JB \& Hayes DF 2006 The measurement and therapeutic implications of circulating tumour cells in breast cancer. British Journal of Cancer 94 8-12.

Smirnov DA, Zweitzig DR, Foulk BW, Miller MC, Doyle GV, Pienta KJ, Meropol NJ, Weiner LM, Cohen SJ, Moreno JG et al. 2005 Global gene expression profiling of circulating tumor cells. Cancer Research 65 4993-4997. 
Smith BM, Slade MJ, English J, Graham H, Luchtenborg M, Sinnett HD, Cross NC \& Coombes RC 2000 Response of circulating tumor cells to systemic therapy in patients with metastatic breast cancer: comparison of quantitative polymerase chain reaction and immunocytochemical techniques. Journal of Clinical Oncology 18 1432-1439.

Solakoglu O, Maierhofer C, Lahr G, Breit E, Scheunemann P, Heumos I, Pichlmeier U, Schlimok G, Oberneder R, Kollermann MW et al. 2002 Heterogeneous proliferative potential of occult metastatic cells in bone marrow of patients with solid epithelial tumors. PNAS 99 2246-2251.

Solomayer EF, Feuerer M, Bai L, Umansky V, Beckhove P, Meyberg GC, Bastert G, Schirrmacher V \& Diel IJ 2003 Influence of adjuvant hormone therapy and chemotherapy on the immune system analysed in the bone marrow of patients with breast cancer. Clinical Cancer Research 9 174-180.

Solomayer EF, Becker S, Pergola-Becker G, Bachmann R, Kramer B, Vogel U, Neubauer H, Wallwiener D, Huober J \& Fehm TN 2006 Comparison of HER2 status between primary tumor and disseminated tumor cells in primary breast cancer patients. Breast Cancer Research and Treatment 98 179-184.

Sopel M, Kasprzyk I \& Berdowska I 2005 Maspin and c-erbB-2 expression in correlation with microvessel density in invasive ductal breast cancer. Folia Histochemica et Cytobiologica 43 109-116.

Sorlie T, Tibshirani R, Parker J, Hastie T, Marron JS, Nobel A, Deng S, Johnsen H, Pesich R, Geisler S et al. 2003 Repeated observation of breast tumor subtypes in independent gene expression data sets. PNAS 100 8418-8423.

Span PN, Waanders E, Manders P, Heuvel JJ, Foekens JA, Watson MA, Beex LV \& Sweep FC 2004 Mammaglobin is associated with low-grade steroid receptor-positive breast tumors from postmenopausal patients, and has independent prognostic value for relapse-free survival time. Journal of Clinical Oncology 22 691-698.

Stathopoulou A, Vlachonikolis I, Mavroudis D, Perraki M, Kouroussis Ch, Apostolaki S, Malamos N, Kakolyris S, Kotsakis A, Xenidis N et al. 2002 Molecular detection of cytokeratin-19-positive cells in the peripheral blood of patients with operable breast cancer: evaluation of their prognostic significance. Journal of Clinical Oncology 20 3404-3412.

Stathopoulos EN, Sanidas E, Kafousi M, Mavroudis D, Askoxylakis J, Bozionelou V, Perraki M, Tsiftsis D \& Georgoulias V 2005 Detection of CK-19 mRNA positive cells in peripheral blood of breast cancer patients with histologically and immunohistochemically negative axillarylymph nodes. Annals of Oncology 16 240-246.

Sternlicht MD, Kedeshian P, Shao ZM, Safarians S \& Barsky SH 1997 The human myoepithelial cell is a natural tumor suppressor. Clinical Cancer Research $\mathbf{3}$ 1949-1958.
Stoeckelhuber M, Messmer EM, Schmidt C, Xiao F, Schubert C \& Klug J 2006 Immunohistochemical analysis of secretoglobin SCGB 2A1 expression in human ocular glands and tissues. Histochemistry and Cell Biology 126 103-109.

Sugita Y, Wada H, Fujita S, Nakata T, Sato S, Noguchi Y, Jungbluth AA, Yamaguchi M, Chen YT, Stockert E et al. 2004 NY-ESO-1 expression and immunogenicity in malignant and benign breast tumors. Cancer Research 64 2199-2204.

Symmans WF, Fiterman DJ, Anderson SK, Ayers M, Rouzier R, Dunmire V, Stec J, Valero V, Sneige N, Albarracin C et al. 2005 A single-gene biomarker identifies breast cancers associated with immature cell type and short duration of prior breastfeeding. Endocrine-Related Cancer 12 1059-1069.

Taback B, Chan AD, Kuo CT, Bostick PJ, Wang HJ, Giuliano AE \& Hoon DS 2001 Detection of occult metastatic breast cancer cells in blood by a multimolecular marker assay: correlation with clinical stage of disease. Cancer Research 61 8845-8850.

Tian W, Osawa M, Horiuchi H \& Tomita Y 2004 Expression of the prolactin-inducible protein (PIP/GCDFP15) gene in benign epithelium and adenocarcinoma of the prostate. Cancer Science 95 491-495.

Tothill RW, Kowalczyk A, Rischin D, Bousloutas A, Haviv I, van Laar RK, Waring PM, Zalcberg J, Ward R, Biankin AV et al. 2005 An expression-based site of origin diagnostic method designed for clinical application to cancer of unknown origin. Cancer Research 65 4031-4040.

Townson JL \& Chambers AF 2006 Dormancy of solitary metastatic cells. Cell Cycle 5 1744-1750.

Trocciola SM, Hoda S, Osborne MP, Christos PJ, Levin H, Martins D, Carson J, Daly J \& Simmons RM 2005 Do bone marrow micrometastases correlate with sentinel lymph node metastases in breast cancer patients? Journal of the American College of Surgeons 200 720-725.

Umekita Y \& Yoshida H 2003 Expression of maspin is up-regulated during the progression of mammary ductal carcinoma. Histopathology 42 541-545.

Umekita Y, Ohi Y, Sagara Y \& Yoshida H 2002 Expression of maspin predicts poor prognosis in breast-cancer patients. International Journal of Cancer 100 452-455.

Valgussa P, Bonadonna G \& Veronesi U 1978 Patterns of relapse and survival following radical mastectomy. Analysis of 716 consecutive patients. Cancer 41 1170-1178.

Varga Z, Theurillat JP, Filonenko V, Sasse B, Odermatt B, Jungbluth AA, Chen YT, Old LJ, Knuth A, Jager D et al. 2006 Preferential nuclear and cytoplasmic NY-BR-1 protein expression in primary breast cancer and lymph node metastases. Clinical Cancer Research 12 2745-2751.

Viehl CT, Tanaka Y, Chen T, Frey DM, Tran A, Fleming TP, Eberlein TJ \& Goedegebuure PS 2005 Tat mammaglobin fusion protein transduced dendritic cells stimulate mammaglobin-specific CD4 and CD8 T cells. Breast Cancer Research and Treatment 91 271-278. 
Wang W, Epler J, Salazar LG \& Riddell SR 2006 Recognition of breast cancer cells by CD8 + cytotoxic T-Cell clones specific for NY-BR-1. Cancer Research 66 6826-6833.

Watson MA \& Fleming TP 1996 Mammaglobin, a mammary-specific member of the uteroglobin gene family, is overexpressed in human breast cancer. Cancer Research 56 860-865.

Watson MA, Dintzis S, Darrow CM, Voss LE, DiPersio J, Jensen R \& Fleming TP 1999 Mammaglobin expression in primary, metastatic, and occult breast cancer. Cancer Research 59 3028-3031.

Weigelt B, Verduijn P, Bosma AJ, Rutgers EJ, Peterse HL \& van't Veer LJ 2004 Detection of metastases in sentinel lymph nodes of breast cancer patients by multiple mRNA markers. British Journal of Cancer 90 1531-1537.

Weigelt B, Hu Z, He X, Livasy C, Carey LA, Ewend MG, Glas AM, Perou CM \& Van't Veer LJ 2005 Molecular portraits and 70-gene prognosis signature are preserved throughout the metastatic process of breast cancer. Cancer Research 65 9155-9158.

Weinschenker P, Soares HP, Clark O \& Giglio AD 2004 Immunocytochemical detection of epithelial cells in the bone marrow of primary breast cancer patients: a meta-analysis. Breast Cancer Research and Treatment 87 215-224.

Welsh JB, Sapinoso LM, Kern SG, Brown DA, Liu T, Bauskin AR, Ward RL, Hawkins NJ, Quinn DI, Russell PJ et al. 2003 Large-scale delineation of secreted protein biomarkers overexpressed in cancer tissue and serum. PNAS 100 3410-3415.

White DE, Rayment JH \& Muller WJ 2006 Addressing the role of cell adhesion in tumor cell dormancy. Cell Cycle 5 1756-1759.

Wicha MS, Liu S \& Dontu G 2006 Cancer stem cells: an old idea - a paradigm shift. Cancer Research 66 1883-1890.

Wiedswang G, Borgen E, Karesen R, Kvalheim G, Nesland JM, Qvist H, Schlichting E, Sauer T, Janbu J, Harbitz T et al. 2003 Detection of isolated tumor cells in bone marrow is an independent prognostic factor in breast cancer. Journal of Clinical Oncology 21 3469-3478.

Wiedswang G, Borgen E, Karesen R, Qvist H, Janbu J, Kvalheim G, Nesl JM \& Naume B 2004 Isolated tumor cells in bone marrow three years after diagnosis in diseasefree breast cancer patients predict unfavorable clinical outcome. Clinical Cancer Research 10 5342-5348.

Wiedswang G, Borgen E, Schirmer C, Karesen R, Kvalheim G, Nesland JM \& Naume B 2006 Comparison of the clinical significance of occult tumor cells in blood and bone marrow in breast cancer. International Journal of Cancer 118 2013-2019.

Wülfing P, Borchard J, Bürger H, Heidl S, Zänker KS, Kiesel L \& Brandt B 2006 HER2-positive circulating tumor cells indicate poor clinical outcome in stage I to III breast cancer patients. Clinical Cancer Research 12 1715-1720.
Xenidis N, Vlachonikolis I, Mavroudis D, Perraki M, Stathopoulou A, Malamos N, Kouroussis C, Kakolyris S, Apostolaki S, Vardakis N et al. 2003 Peripheral blood circulating cytokeratin-19 mRNA-positive cells after the completion of adjuvant chemotherapy in patients with operable breast cancer. Annals of Oncology 14 849-855.

Xenidis N, Perraki M, Kafousi M, Apostolaki S, Bolonaki I, Stathopoulou A, Kalbakis K, Androulakis N, Kouroussis C, Pallis T et al. 2006 Predictive and prognostic value of peripheral blood cytokeratin-19 mRNA-positive cells detected by real-time polymerase chain reaction in nodenegative breast cancer patients. Journal of Clinical Oncology 24 3756-3762.

Xiao F, Mirwald A, Papaioannou M, Baniahmad A \& Klug J 2005 Secretoglobin $2 \mathrm{~A} 1$ is under selective androgen control mediated by a peculiar binding site for Sp family transcription factors. Molecular Endocrinology 19 2964-2978.

Zach O \& Lutz D 2006 Tumor cell detection in peripheral blood and bone marrow. Current Opinion in Oncology 18 48-56.

Zafrakas M, Petschke B, Donner A, Fritzsche F, Kristiansen G, Knuechel R \& Dahl E $2006 a$ Expression analysis of mammaglobin A (SCGB2A2) and Lipophilin B

(SCGB1D2) in more than 300 human tumors and matching normal tissues rveals their co-expression in gynaecological malignancies. BMC Cancer 688.

Zafrakas M, Chorovicer M, Klaman I, Kristiansen G, Wild PJ, Heindrichs U, Knüchel R \& Dahl E 2006b Systematic characterisation of GABRP expression in sporadic breast cancer and normal breast tissue. International Journal of Cancer 118 1453-1459.

Zehentner BK $2002 a$ Detection of disseminated tumor cells: strategies and diagnostic implications. Expert Reviews in Molecular Diagnostic 2 89-96.

Zehentner BK, Dillon DC, Jiang Y, Xu J, Bennington A, Molesh DA, Zhang X, Reed SG, Persing D \& Houghton RL 2002b Application of a multigene reverse transcription-PCR assay for detection of mammaglobin and complementary transcribed genes in breast cancer lymph nodes. Clinical Chemistry 48 1225-1231.

Zehentner BK, Persing DH, Deme A, Toure P, Hawes SE, Brooks L, Feng Q, Hayes DC, Critichlow CW, Houghton RL \& Kiviat NB 2004 Mammaglobin as a Novel Breast Cancer Biomarker: Multigene Reverse Transcription-PCR Assay and Sandwich ELISA. Clinical Chemistry 50 2069-2076.

Zhang W \& Zhang M 2002 Tissue microarray analysis of maspin expression and its reverse correlation with mutant p53 in various tumors. International Journal of Oncology 20 1145-1150.

Zhang M, Volpert O, Shi YH \& Bouck N 2000 Maspin is an angiogenesis inhibitor. Nature Medicine 6 196-199.

Zhong XY, Kaul S, Eichler A \& Bastert G 1999 Evaluating GA733-2 mRNA as a marker for the detection of micrometastatic breast cancer in peripheral blood and bone marrow. Archives of Gynecology and Obstetrics 263 2-6. 
Zhu L, Loo WT \& Chow LW 2005 Circulating tumor cells in patients with breast cancer: possible predictor of micrometastasis in bone marrow but not in sentinel lymph nodes. Biomedicine and Pharmacotherapy 59 S355-S358.

Zidan J, Dashkovsky I, Stayerman C, Basher W, Cozacov C \& Hadary A 2005 Comparison of HER2 overexpression in primary breast cancer and metastatic sites and its effect on biological targeting therapy of metastatic disease. British Journal of Cancer 93 552-556.

Zieglschmid V, Hollmann C \& Böcher O 2005 Detection of disseminated tumor cells in peripheral blood. Critical Reviews in Clinical Laboratory Sciences 42 155-196.

Zou Z, Anisowicz A, Hendrix MJ, Thor A, Neveu M, Sheng S, Rafidi K, Seftor E \& Sager R 1994 Maspin, a serpin with tumor-suppressing activity in human mammary epithelial cells. Science 263 526-529. 